Discussion Paper Series A No.500

The Effect of Participation in Government Consortia on the R\&D Productivity of Firms:

A Case Study of Robot Technology in Japan

Sébastien Lechevalier
(Foreign Visiting Researcher, The Institute of Economic Research,

Hitotsubashi University/EHESS \& Maison Franco Japonaise),

Yukio Ikeda

(Faculty of International Social Science Studies,

Yokohama National University and Maison franco-japonaise) and

Junichi Nishimura

(Faculty of Economics, Hitotsubashi University

and Maison franco-japonaise)

March, 2008

The Institute of Economic Research

Hitotsubashi University

Kunitachi, Tokyo, 186-8603 Japan 


\title{
The Effect of Participation in Government Consortia on the R\&D Productivity of Firms: A Case Study of Robot Technology in Japan
}

\author{
Sébastien Lechevalier ${ }^{\mathrm{a} 1}$, Yukio Ikeda ${ }^{\mathrm{b}}, \&$ Junichi Nishimura ${ }^{\mathrm{c}}$ \\ ${ }^{a}$ EHESS (Paris), Maison franco-japonaise (Tokyo) \& Hitotsubashi University \\ ${ }^{\mathrm{b}}$ Yokohama National University \& Maison franco-japonaise \\ ${ }^{c}$ Hitotsubashi University \& Maison franco-japonaise \\ Maison franco-japonaise, 3-9-25 Ebisu, Shibuya-ku, Tokyo, JAPAN
}

March 2008

${ }^{1}$ Corresponding author. Email: sebastien.lechevalier@ehess.fr 


\section{The Effect of Participation in Government Consortia on the R\&D Productivity of Firms: A Case Study of Robot Technology in Japan}

Summary: This paper examines the effect of participation in government-sponsored R\&D consortia on the $R \& D$ productivity of firms in the case of robot technology in Japan. We attempt to provide a new empirical analysis and discussions on the issue of government project evaluation by using indicators of the quality of patents, by investigating the impact of the evolution of government programs, and comparing governmentsponsored R\&D consortia with collaborative R\&D among firms.

Using indicators of the quality of patents which enables us to provide an estimation of quality-adjusted research productivity, we find that participation in government programs has a positive impact on the research productivity of participating firms, but the impact of participation became much higher after the design of government programs in this field changed in the late 1990s. Also, we find that participation in governmentsponsored consortia has a greater impact on research productivity than participation in collaborative R\&D among firms. This may support government involvement in $R \& D$ as a coordinator of $R \& D$ collaboration.

JEL Classification: L24, L52, L6, O32, O34, O38

Key words: industrial policy, robot technology, Japanese innovation system, collaborative R\&D. 


\section{Introduction}

Economists generally agree that the market will fail to generate a sufficient level of R\&D as the knowledge stock generated by R\&D activity inherently has certain characteristics of public goods and thus encourages government involvement in promoting R\&D. However, this does not mean that government policy on R\&D can always be justified. One important counterargument for government involvement is that it may crowd out private $R \& D$ instead of complementing it. There is, in fact, no clear consensus among economists as to under which conditions government involvement in $\mathrm{R} \& \mathrm{D}$ activities is effective.

Setting up government-sponsored consortia is one of the policy methods used to promote the R\&D activities of firms. ${ }^{2}$ There are actually vast accumulations of theoretical studies that examine the benefit of government-sponsored consortia as a way to ameliorate this market failure, ${ }^{3}$ yet very little has been done to systematically examine these theories with a large number of samples. ${ }^{4}$ Examples of these empirical researches is Branstetter and Sakakibara (1998) and Branstetter and Sakakibara (2002). There are also a number of studies that analyze government involvement in the pharmaceutical industry, examples of which include Okada et al. (2003) and Okada et al. (2006). ${ }^{5}$

This paper empirically analyzes the publicly sponsored consortia in the field of robot technology (RT). In the last two decades, RT has undergone dramatic technological development and attracted a lot of public attention, yet has been relatively neglected in the economic literature. We analyze these public consortia based on the technique introduced by Branstetter and Sakakibara (1998), which uses the number of patents applied for by firms as a proxy to measure innovation. Yet we also extend the analysis in the following ways. First, instead of using the number of patents to measure innovation, we use indicators of the quality of patents, such as the number of claims and citations. This allows us to estimate the impact of public consortia on quality-adjusted research productivity. Second, we closely look at the evolution of the design and organization of government programs on RT and

\footnotetext{
${ }^{2}$ Other policy methods include special tax treatment on tax, subsidies, and the promotion of R\&D activities in universities and public institutions (Guellec and van Pottelsbergue de la Potterie, 2003).

${ }^{3}$ Examples include Spence (1984), Katz (1986), and D'Aspremont and Jacquemin (1988).

${ }^{4}$ Indeed, there are a number of empirical studies that analyze innovation policy based on case studies. Examples include Irwin and Klenow (1996), Link et al. (2000), and Odagiri et al. (1997).

${ }^{5}$ Okada et al. (2006) examines Japanese biomedical patents between 1991 and 2002 and finds that patent fields by a corporation and joint applications by corporations are highly valued and, if a corporation is the first assignee, a patent with a government coassignee is highly valued.
} 
empirically analyze the effects of the evolution. Third, we take into account the fact that governmentsponsored $R \& D$ consortia are just one type of $R \& D$ collaboration, and there also exists $R \& D$ collaboration among the firms without government involvement. Indeed, the theoretical justification of government involvement in $\mathrm{R} \& \mathrm{D}$ activities lies in industrial organization theories such as Spence (1984) and Katz (1986), which state that market failure can be mitigated by R\&D collaboration. In this paper, we define government-sponsored consortia as government-coordinated R\&D collaboration, and define $R \& D$ collaboration which is engaged in by firms without government involvement as market-coordinated R\&D collaboration. A comparison of the impact between these two types of R\&D collaboration is then made. We think the result of this comparison has an important implication because, if the market can solve the market failure of $R \& D$ activities in the form of collaboration among firms, certain grounds justifying government involvement are lost.

The subsequent sections are organized as follows. Section 1 briefly overviews the theoretical and empirical literature on government-sponsored $R \& D$ consortia. It also provides a brief description of RT-related publicly funded consortia in Japan. Section 2 presents the dataset used in our analysis and underlines the definitions of the kind of patents used in the analysis. In Section 3, we propose 4 hypotheses that will be tested and specify our empirical models. Section 4 shows the results of our quantitative analysis and our interpretation of them.

\section{Government-sponsored consortia: a review of the literature and the case of robot technology}

\subsection{Review of the literature on government-sponsored $R \& D$ consortia}

The theoretical explanation to justify government-sponsored R\&D can be found in the industrial organization theory of R\&D collaboration. The pioneering study by Spence (1984) clearly states that the existence of knowledge spillovers leads to incomplete appropriability of the R\&D results, which gives rise to market failure. Accordingly, the equilibrium level of R\&D is deemed to be significantly lower than the socially optimum level. The enhancement of intellectual property rights corrects the incentive problem of R\&D but will create the duplication of R\&D activities and hence an excessive 
level of R\&D. In this context, R\&D collaboration can mitigate the tradeoff between the incentives for appropriation and the duplication of R\&D and provide a solution for the dilemma. Katz (1986), however, indicates that the incentive to form $\mathrm{R} \& \mathrm{D}$ collaboration can be affected by the states of the ex post market competition. If a firm tries to conduct R\&D collaboration with a partner that competes in the market, part of the rent born out of the research can be lost in the subsequent market competition. Thus, if the market competition among the collaborating firms is intense, the incentive to undertake $R \& D$ collaboration will be quite weak, which results in a less-than-optimal R\&D level.

The economic literature also identifies several potential conduits whereby government R\&D projects benefit private R\&D. For example, David et al. (2000) lists the following three mechanisms through which public R\&D stimulates complementary private $R \& D$ expenditures:

1) Publicly supported R\&D generates learning effects which enhance the ability of private firms to obtain the latest scientific and technological knowledge. (Absorptive capacity)

2) Using public funds to enable the use of experimental facilities and research facilities and having the government assume the fixed costs for establishing specific R\&D projects allows private firms to start projects with low additional costs. This increases the expected return on R\&D investment. (Cost sharing)

3) Commissioned R\&D signals future demand in the public sector and demand for goods and services diverted to the private sector. Accordingly, this increases the expected return on R\&D investment. (Pump-priming effect).

Another important channel whereby government projects benefit private $R \& D$ is the promotion of trust among collaborative R\&D players (institutional-building trust), which enhances their social network for innovation. For example, Darby et al. (2003) empirically analyzes the effect of the Advance Technology Program (ATP) on firms' innovation and states that "the implicit design of ATP encourages firms to relax their boundaries and share knowledge. Firms participating in ATP gain from the project, learn from each other, and become better at innovating." (Darby et al.: 2003, p.5). The implicit institutional design that promotes trust among participants includes, for example:

- Third-party (ATP) monitoring of participants' behavior in joint ventures to ensure cooperation (Zucker et al., 1996); 
- Administrative structures and agreements such as intellectual property agreements, joint venture administrative structures to increase confidence in successful coordination (Das and Teng, 1998).

Compared to the large volume of theoretical literature that has been developed so far, little has been done to empirically test the validity of these theories using a relatively comprehensive dataset. There are, however, some exceptions. For example, Branstetter and Sakakibara (1998) uses a sample of 145 government-sponsored R\&D consortia in Japan and finds that frequent participation in these consortia has a positive impact on the level of research expenditure and research productivity. Also, Branstetter and Sakakibara (2002) uses the same dataset and finds that the outcomes of consortia are positively related to the level of potential spillovers within consortia and negatively related to the degree of product market competition among participating firms.

These empirical studies provide valuable insights on the effects of government-sponsored consortia. Yet it is important to note that one can also find many cases of research collaboration between firms without government involvement. Thus, even if we find positive effects of governmentsponsored consortia on the level and productivity of $\mathrm{R} \& \mathrm{D}$, it does not necessarily justify government involvement, as these examples of government-sponsored $R \& D$ collaboration could have been voluntarily realized by the decisions of private firms. Thus, in the later part of this paper, we conduct an empirical analysis that compares the two types of R\&D collaboration: government- coordinated R\&D collaboration (government-sponsored consortia) and market-coordinated R\&D collaboration (R\&D collaboration among firms without government involvement).

\subsection{Overview of the robot technology related government-sponsored R\&D consortia in}

\section{Japan}

There has been a series of new movements in R\&D and dramatic technological advances in robotics technologies since the early 1980s. Namely, many firms have invested a lot of effort inventing service robots, which can be used outside factories, in places such as households and public areas, as well as new types of industrial robots characterized by more autonomy. These two types of robots have been categorized as "next generation robots." The R\&D in these new technologies in RT has 
actually attracted a great deal of public attention, and central and local governments support this industry in the form of public projects and subsidies.

RT-related public projects have been extended to the domain of various ministries in central government. Among these, only the Ministry of Economy, Trade, and Industry (METI) and the Ministry of Internal Affairs and Communication (MIC) have had relatively comprehensive views on industry-wide technological development, and the biggest share of the budget of the RT-related projects is assigned to METI. Our empirical study focuses on the projects led by these two ministries that have been characterized by important developments in their goal and design, as detailed below. We mention briefly here the projects in other ministries (the Ministry of Education, Culture, Sports, Science and Technology, the Ministry of Health, Labor and Welfare, the Ministry of Land, Infrastructure and Transport, and the Ministry of Agriculture, Forestry and Fisheries), which are more focused on very specific issues which relate to RT.

Public Projects by METI. Most of the RT-related public projects which are planned by METI are carried out by its R\&D agency, NEDO. One can see the change in the nature of the involvement of METI and NEDO on RT in the later 1990s when the Humanoid Robotics Projects or HRP (1998-2002), which was the first comprehensive project, was implemented. In the pre-HRP period, METI had conducted various RT-related projects with very specific purposes, and there was no general strategy on the development of the industry. The projects that were carried out in this period include the "Robot for Hazardous Zones" (1983-1991), "R\&D on Micromachine Technology" (1991-2000), the "Mobile Meal Delivery Robot for Aged and Disabled People" (1995-1999), and "The Surgery Support System for Brain Tumors" (1998-2000).

The HRP project was the first comprehensive project which had an industry-wide strategic view. The purpose of the project was to develop humanoid robots, such development being thought likely to bring about significant technological breakthroughs and various commercial applications, such as security services for plants, construction work, nursing care support, and management services for building or houses. Various manufacturing firms participated in this project, including Honda, which was considered to be the leading firm in this field. The development of comprehensive 
hardware (HRP-2) and comprehensive software (OpenHRP) are examples for the outcomes of this project. Even though this project achieved some of its technological goals, it did not generate any commercial outcomes. There has been criticism that the goal of the project was too vague, and that there was no clear view of how to connect the R\&D to commercial applications.

The implementation of post-HRP projects has reflected these evaluations of the HRP project and has focused more on problem-finding and -solving and on practical uses of robot technologies. In 2002, the $21^{\text {st }}$ Century Robot Challenge Program was established. It connected all the related robot projects (Figure 1). A main characteristic of this program is the aim to do research on the common and basic technologies necessary for the development of robots. It includes the "Humanoid Robot Project" (1998-2002), the "Project for the practical application of Next generation robots" (2004-2005), and the "Development of a Software Infrastructure for robot systems" ("RT Middleware project," 2002-2004).

\section{$===$ Insert Figure 1 around here $===$}

In 2003, the first meeting of the Robot Vision Kondankai (committee) was held, with important figures in the academic and business worlds discussing the problems faced in this field. ${ }^{6}$ In 2006, METI proposed a New Industries Creation Strategy (NICS), and RT was selected as one of the priority industries. The recent RT projects have been carried out based on the proposals laid out in the committee reports and the action plan in the NICS. One characteristic of these public projects is the division of technological themes. Currently, the themes in the whole project are grouped into systematization technology, base technology, and elements technology, and the targets of each theme and the relation between them is clearly specified. The other characteristic is that users of the robots (such as securities companies) as well as the manufacturers are stimulated to take part. This is an attempt to integrate the user's point of view into the projects to realize practical applications out of the projects.

\footnotetext{
${ }^{6}$ Another committee for an RT-related project (Robot Policy Kenkyukai) was established in 2005.
} 
Public Projects by MIC. MIC has been engaged in public projects on network robots, which can provide a high quality of services by using a network. As it involves communication technologies, in which MIC has administrative authority, the public policies for the network robots at the central government level have been solely administered by MIC. In 2004, MIC started a network-robotrelated R\&D project, "Network Robot with Ubiquitous Network Technologies and Robot Technologies." The target of this project is supposed to establish the necessary component technology to materialize network robots conducting R\&D on ICT by 2008 .

MIC administers the National Institute of Information and Communications Technology (NICT) as an incorporated administrative agency, and the robot-related projects which were planned by MIC have been carried out by NICT.

Public Projects by MEXT (the Ministry of Education, Culture, Sports, Science and Technology). There have been two major projects funded by MEXT: the "MEXT Special Project for Earthquake Disaster Mitigation in Urban Areas" (DDT Project) and "Bio-Mimetic Control Research." The DDT Project is aimed to promote $R \& D$ for disaster mitigation in urban areas, and one of its programs includes robotics-related technology. This program has been administrated by a Non-Governmental Organization, the International Rescue System Institute (IRS), and was been carried out between 2002 and 2007. Bio-Mimetic Control Research was conducted by Riken, which is an Independent Administrative Institution (IAI) subordinated to MEXT. The main topics of this project include biological control systems and biologically integrative sensors and the aim of the project is to create advanced engineering systems such as a soft human interactive robot. In addition, certain (small) robotics-related research programs have been funded through JST, a project-oriented funding agency (IAI) under MEXT.

Other Public Projects. The Ministry of Land Infrastructure and Transport is conducting two projects which aim to apply robotics-related technologies to construction and infrastructure building, and these two are "The Development of IT Construction System by Robotics" and "Research on the Operation of and Surveillance by Underwater Robots." The Ministry of Health, Labour and Welfare (MHLW) 
funded a research grant, "R\&D for Human Body Analysis, Support, and Substitution Instrument" (2003-2008), which aims to promote new medical instruments to substitute the human labor and support the human body. The Ministry of Agriculture, Forestry and Fisheries (MAFF) funded "The Emergent Development of Next Generation Agricultural Machines Project”, which aims to rapidly develop high-quality agricultural machines that will save energy, cost, and environmental damage by the cooperative research of firms, universities, and governmental agencies such as the Bio-oriented Technology Research Advancement Institution.

Inter-ministerial coordination. It is important to note that the public projects of each of these ministries have been planned and carried out independently, and there has been virtually no interministerial coordination. However, in 2004, the Council for Science and Technology Policy (CSTP) decided to promote cooperation among ministries in important technological fields, and RT was selected as one of the Cooperative Policy Groups. Based on this, four RT-related public projects were carried out in 2004 and 2005 through the funding of MEXT to complement the existing projects. CSTP has recently launched a program that evaluates the technology policies of important technological fields among the ministries in an attempt to coordinate the various ministries in these fields. The actual administrative work for this program is commissioned to JST (Japan Science and Technology Agency), an organization related to MEXT.

Characteristics of the firms that are involved with RT and RT-related public projects. There are a variety of participating firms in the public projects of RT, and it is possible to categorize them into at least three groups. One group is composed of companies that are specialized in RT. They include large firms like Fanuc and Yaskawa and a number of start-up companies like Tmsuk. A second group is composed of very large companies in the machinery sector (including electrical machinery and car industries) like Hitachi, Toshiba, or Mitsubishi Heavy Industries. They are often the clients of the firms of the former group and are engaged in RT in an attempt to diversify their activities. The third group includes potential users of service robots like SECOM, a security company. 
Generally speaking, the participants are very big companies, but some robot makers appear to be reluctant to be involved in government-sponsored consortia, probably because they are unwilling to disclose information. One can also note that there is considerable heterogeneity in participation frequency among firms. For example, for 17 commissioned programs between 1991 and 2005, the most frequently participating firms are Hitachi (7 times), Toshiba (7), and Mitsubishi Heavy Industries (6), whereas Toyota and Sony have never participated.

In the following sections, we empirically analyze the RT-related government-sponsored consortia. However, due to lack of data, especially regarding patents that are assigned to the consortia, we do not cover all RT-related consortia but focus on 12 R\&D consortia, as listed in Appendix 1, including 9 projects by NEDO (METI) and 3 by NICT (MIC).

\section{Data}

The main purpose of this paper is to empirically assess RT-related government projects, and our empirical strategy is to use information about patents that derive from the public projects and compare them with other patents. To do this, we first collected complete data on RT-related patents and identified those that derive from public projects.

\subsection{The dataset}

We use two complementary data sources: the Industrial Property Digital Library or IPDL ("koho text kensaku") and Standardized Data ("Seiri-Hyojunka Data"). The IPDL data enable us to clearly classify 4 macro- and 26 micro-technological fields of RT (Figure 2). However, for some reason, the JPO (Japan Patent Office) does not give information on 6 categories ("other robots," "modular structures," “attachments," "control units operated by foot," "virtual reality," and "networking technology"). ${ }^{7}$ So we limit the analysis to 20 technological fields. Moreover, the IPDL only covers the patents from around 1991 and does not contain information on citations. On the other hand, the Standardized Data do include such information. Yet we cannot clearly identify the RT-related patents, and it covers

\footnotetext{
${ }^{7}$ We did not receive a satisfying answer from the JPO as to why they are not available. This is probably due to identification problems for these six technologies.
} 
patents until around 2001. Therefore we have merged these two data sources to get a more complete dataset.

$$
===\text { Insert Figure } 2 \text { around here }===
$$

We collected 16,736 patent numbers through the IPDL $(12,863$ patents of the total are matched with the Standardized Data). Among these patents, we extracted patents applied for by Japanese companies. ${ }^{8}$ Then, we created unbalanced panel data organized by company and year. We found, however, that many firms have only a small numbers of patents and that it is difficult to assess the $R \& D$ productivity (quality of patents) for these firms. After having analyzed the distribution of the number of patents per firm, we found that 5 patents per firm was a meaningful threshold for analysis and we have excluded all firms which have less than five patents. In sum, our sample includes 316 companies and 13,711 patents, ${ }^{9}$ with a sampling period between 1991 and 2004.

\subsection{Definition and distribution of $G$ patents}

As a next step, we identified the patents that came out of the 12 projects by NEDO and NICT out of these 13,711 patents. We did this by referring to the official reports of these projects. We define these patents as G1 patents and found that there are 94 such patents in the database.

Table (1) shows the distribution of G1 patents by project, by comparison to that of non-G1 patents. We find that the ratio of G1 patents is much higher than that of non-G1 patents in some technological fields, including mobile robots, artificial intelligence, control of mobile robots, image processing, and sound recognition. These technologies are closely related with next-generation robots and science (Figure 2). This implies that government projects focus on those frontier technologies which are difficult for one company to conduct $R \& D$ in.

$===$ Insert Table 1 around here $===$

\footnotetext{
${ }^{8}$ We checked the inventors of all patents one by one, and created a database on their affiliated companies using various search engines (see Lechevalier, Ikeda, and Nishimura (2006) for more details).

${ }^{9}$ Among these patents, some patents overlap because they are collaborative patents.
} 
Moreover, as the number of G1 patents is small relative to non-G1 patents $(13,711-94=13,617)$, we borrowed the methodology used by Branstetter \& Sakakibara (2002) and include the patents applied for by participating firms in the targeted technologies during and after consortia as the outcomes of these consortia. We define these patents as G2 patents and the sum of the G1 and G2 patents as government $(\mathrm{G})$ patents. Similarly, $G$ firms are defined as the firms which applied for at least one G patent (G1 or G2). The definition of G2 patents is further explained in Appendix 2.

Even though we basically use G1 patents for our empirical analysis, we also utilize G2 patents to check the robustness of the results we obtain with G1 patents. ${ }^{10}$

\section{Hypotheses and Empirical Specifications}

\subsection{Hypotheses}

Based on the discussion in Section 1, we set the following predictions:

1. Participation in government-sponsored consortia leads to an increase in the research productivity of participating firms.

2. One of the channels through which participation in government-sponsored consortia increases research productivity is knowledge spillovers.

3. As discussed in Section 1.2, the design of government programs on RT has been better articulated over time. We hypothesize that the magnitude of the impact of participation in governmentsponsored consortia on the R\&D productivity of firms has changed over time as the design of the programs has changed.

4. The impact of government-sponsored $R \& D$ consortia on research productivity differs from the market-coordinated type of R\&D collaboration.

The rest of this section specifies the models we will use to test the hypotheses above. We basically follow the technique used by Branstetter and Sakakibara [1998] for our model building.

\footnotetext{
${ }^{10}$ There is another ground to use G2 patents, which stems from the fact that the strategy of the government on patents has changed over time. Branstetter \& Sakakibara (1998: 213) points out that "Prior to 1990, many if not most of the patents to directly emerge from the research undertaken within government-sponsored research consortia were, by government directive, assigned not to the participating firms but instead to the research consortia themselves." Thus, the change of government policy in the 1990s may have led to an underestimation of the outcomes of the public projects if we define them strictly based on the G1 definition.
} 


\subsection{A Model of Research Productivity}

We first specify the model of research productivity. We assume that the productivity of the $R \& D$ activities is a function of firm level $R \& D$ spending and the intensity of participation in consortia.

$$
N_{i}=f\left(R_{i}, C_{i}\right)
$$

where $N_{i}$ is innovation, $R_{i}$ is $\mathrm{R} \& \mathrm{D}$ spending, and $C_{i}$ is intensity of participation to consortia. We assume that this relation is in linear form.

$$
N_{i t}=\beta_{0}+\beta_{1} R_{i t}+\beta_{2} C_{i t}+\mu_{i t}
$$

One important problem in estimating this model is which proxy measures for the unobservable "innovation" will be used. Here we use two proxies: the number of claims and forward citations for patent. ${ }^{11}$ The claims in the patent specification delineate the property rights protected by the patent. The larger the number of claims, the broader and the greater the expected profitability of an innovation is. Forward citations are the number of times that a patent is cited by other patents in the following years. Thus, a large number of forward citations suggests that the patent is highly evaluated by others.

These two variables are considered to be proxies to measure "quality-adjusted R\&D productivity." Although the number of patents has often been used as a proxy for "innovation" (Sakakibara \& Branstetter, 1998, 2002; Darby et al., 2003), this practice has been discussed and the numbers of claims and forward citations have been alternatively used as proxies for the outcome of innovation activities. ${ }^{12}$ For example, Tong and Frame (1994) compare the number of claims with the number of patents and found that patent claims appear to offer a better indicator of inventiveness than the number of patents. ${ }^{13}$

\footnotetext{
${ }^{11}$ However, as there are considerable citation lags in forward citations, we were not able to get data for the most recent years. Therefore, we mainly use the number of claims as a dependent variable and use the number of forward citations only complementarily.

${ }^{12}$ The number of citations has been available only recently in the case of Japanese patents. As for the number of claims, identification for each patent is very time consuming. This may explain why the number of patents has been preferred in many studies.

${ }^{13}$ Likewise, Trajtenberg (1990) shows that there is a close relation between the number of patents weighted by forward citations and the social value of innovations in the computer tomography scanner industry. Another example is the paper by Lanjouw and Schankerman (2004), who construct a composite index which includes claims, forward citations, and backward
} 
Concerning R\&D spending, it would be desirable to collect data on R\&D expenses in the RT field by each firm. It is, however, very difficult to obtain these data. We may be able to use the total R\&D expenses of each firm, but it appears not to be appropriate as the R\&D activities in the RT area seem to be a very small part of the total R\&D activities of the firms, especially in the case of large firms involved in RT. In order to solve this problem, we make use of the number of inventors as a proxy for R\&D expenses. ${ }^{14}$ This variable is considered to be a proxy for the scale of a research project and the accumulation of human capital, as the larger the number of inventors of a patent, the bigger the research project is. Goto et al. (2006) and Mariani and Romanelli (2006) use the number of inventors as a proxy for $R \& D$ expenses and find that this variable has a significant and positive impact on $R \& D$ productivity.

There is one important issue in estimating this model, which is the possibility of endogeneity of the second explanatory variable, $C_{i t}$. It is natural to think that the selection of the participating firms is affected by multiple factors. In particular, METI officials are likely to assign projects to firms with high research quality (subjective or not). Accordingly, even if we find there is positive relation between research productivity and the intensity of participation, it may be high research productivity that leads to the higher participation intensity, rather than the other way around. The estimates of (2) would then be inappropriate (Branstetter \& Sakakibara, 1998).

We thus estimate the following two models, instead of (2), to deal with this problem. First, we assume that the unobserved "quality" of the firm $i$ affects the intensity of the participation of firm $i$. In other words, there is an unobserved time constant firm effect which is correlated to the explanatory variable, $C_{i t}$. That is,

$$
N_{i t}=\beta_{0}+\beta_{1} R_{i t}+\beta_{2} C_{i t}+q_{i}+v_{i t}
$$

\footnotetext{
citations. They find that the most important indicator for the quality of patents is the number of claims in most industries except in the case of the drugs industry.

${ }^{14}$ In the subsequent econometric analysis, we also use the number of patent applications as a proxy for R\&D expenses in the RT field. The correlation between the number of patent applications and R\&D expenses is high (0.982 in Japan, Tong and Frame, 1994). In fact, the estimation results do not change much when we use the number of applications instead of the number of inventors.
} 
where $q_{i}$ is a time constant quality of firms and $v_{i t}$ is idiosyncratic errors. To estimate this model, we use a fixed effects estimator which is a consistent estimator if this is the case.

The other approach is to assume that the explanatory variable, $C_{i t}$, is correlated with a timevariant unobserved effect, $q_{i t}$. If this is the case, the fixed effects estimator is deemed to be inconsistent, as the explanatory variable and disturbance are contemporaneously correlated. In order to solve this problem and provide a consistent estimation, we conduct a 2SLS estimation following Wooldridge (2002). This can be done by obtaining the predicted values of $C_{i t}$, regressing against the instrument variables which are correlated with $C_{i t}$ but exogenous to the dependent variables.

$$
\widehat{C}_{i t}=\sum \theta_{k} \text { Instruments }_{i t}+\varepsilon_{i t}
$$

Then we estimate the original model using the predicted values of $C_{i t}$, which were obtained by (4).

$$
N_{i t}=\beta_{0}+\beta_{1} R_{i t}+\beta_{2} \widehat{C}_{i t}+w_{i t}
$$

The dependent variable of the models (the number of claims) is a count variable that takes on nonnegative integer values and its distribution does not follow normal distribution. The Poisson Regression and Negative Binomial Regression models are the two common estimators for count data. One assumption of the Poisson Regression model is that its mean is equal to its variance. Looking at the characteristics of our data concerning the number of claims, it appears that the observed variance is greater than the mean (the sample average is 32.3 and the standard deviation is 91.6). The estimation of the Poisson Regression model seems to lead to overdispersion. Thus, we choose to use the Negative Binomial Regression model.

\subsection{A Model to Estimate Spillover Effects}

To see whether the impact on knowledge spillovers is one of the channels of the effects of consortia on research productivity, we introduce a variable, the spillover pool, as suggested by Jaffe 
(1986). The spillover pool is an indicator to measure potential spillover effects that a firm can gain. The spillover pool for firm $i$ in time $t$ is formularized as:

$$
K_{i t}=\sum_{i \neq j} T_{i j} R_{j t}
$$

where $R_{j}$ is the number of patent applications of firm $j$, and $T_{i j}$ is the "technological distance" between firms $i$ and $j$. It can be thought as the sum of knowledge stock of other firms weighed by the technological distance to firm $j .{ }^{15}$

We assume that a higher intensity of participation leads to a higher absorptive capacity to utilize the potential spillover pool; in other words, frequent participation will yield higher research productivity elasticity. Thus, the research productivity function will be

$$
N_{i}=f\left(R_{i},\left(K_{i} C_{i}\right)\right)
$$

We assume the function takes linear form:

$$
N_{i t}=\beta_{0}+\beta_{1} R_{i t}+\beta_{2} C_{i t} * K_{i t}+\mu_{i t}
$$

where Nit is innovation, Rit is R\&D spending, Cit is intensity of participation, and $\mu_{i t}$ is an error term with fixed effects and random errors.

\subsection{Impact of the evolution of the program}

As indicated in Section 1.2, a conspicuous change in the nature of the RT-related projects of METI occurred in the late 1990s. Until that time, there was no ground design for the development of RT, but, by that time, METI started to have an industry-wide strategic view, which can be seen through the launching of the HRP project (1998) and the formation of a kondankai (committee) in

\footnotetext{
${ }^{15}$ A more detailed derivation of the spillover pool is provided in Appendix 3.
} 
2003. We hypothesize that the effects of participation in public projects on research productivity differ between these periods as the nature of the projects changed. ${ }^{16}$

To test this hypothesis, we use year dummy variables and a Chow test to see if there is any structural break in the impact of participation during the sample period. We first create a dummy variable, from 92, which takes 1 for the period after 1992 and takes 0 before this period. Then, we include the cross term of Cit and the dummy variable, from92, into the model (8). Therefore, we estimate the following model:

$$
N_{i t}=\beta_{0}+\beta_{1} R_{i t}+\beta_{2} C_{i t}+\beta_{3} C_{i t} * \text { from } 92+\mu_{i t}
$$

If the coefficient of the cross term, $C_{i t} *$ from 92 , is statistically significant, it implies that there is a difference in the impact of participation before and after 1992. We then create dummy variables from 93, from 94...from04, in the same way as from 92: they take the value 1 after the year indicated in the names of variables and 0 before. We replace the dummy variables one by one and estimate models with each dummy variable.

Furthermore, based on these regressions, we conduct a Chow test. By looking at the coefficients of each estimated model and the result of the Chow test, we can see if there is a structural break in the impact of participation during the sample period and when the structural break happens.

\subsection{Impact of Two Types of Collaboration on Spillover Effects}

We define government-sponsored consortia - or government-coordinated collaboration - as one type of collaborative R\&D activities. We hypothesize that the impact of government-coordinated collaboration differs from that of collaborative research among firms - or market-coordinated collaboration. To test this hypothesis we estimate the following equation, which is based on equation (8), which allows us to take into account market-coordinated collaboration and compare its impact to that of government-coordinated collaboration:

\footnotetext{
${ }^{16}$ This discussion basically concerns the 9 METI projects of our sample of 12 consortia. Regarding the 3 MIC projects, it is difficult to discuss whether their nature changed, as they started after 2000. However, we may consider their organization to perhaps have been indirectly influenced by METI's experience in the field, even if the coordination between the two ministries is limited.
} 


$$
N_{i t}=\beta_{0}+\beta_{1} R_{i t}+\beta_{2} K_{i t} * C P_{i t}+\beta_{3} K_{i t} * C G_{i t}+\mu_{i t}
$$

where $C G_{i t}$ is the frequency of participation in the government-sponsored consortia for firm $i$ in time $t$ and $C P_{i t}$ is the frequency of collaboration with other firms for firm $i$ in time $t$.

One problem in estimating this equation is that information on cooperation among firms is not readily available, as the firms are usually reluctant to disclose it. We therefore identify collaborative R\&D among firms by looking at information on the inventors of each patent. We define a "collaborative patent" as a patent that includes more than two inventors, who are affiliated to different organizations. ${ }^{17}$ Then, we use these "collaborative patents" as proxies for collaborative R\&D among firms. ${ }^{18}$

Another point concerns the distinction between the effects of past and current participation on research productivity. Experience can be regarded as a proxy for the transaction cost of participating in government projects. Prior experience in negotiating, writing contracts, participating in a committee, and collaborating with participants will lower the cost and help participants to collaborate smoothly with project members and government officials. That is why we think that it is important to differentiate the effect of past participation from current participation, by using two kinds of variables for $C G_{i t}$ and $C P_{i t}$. The first type is the accumulated number of $\mathrm{G}$ patents and collaborative patents applied by firm $i$ before time $t$. It allows us to analyze the impact of past involvement in collaboration on research productivity. ${ }^{19}$ We name these variables $P C G_{i t}$ and $P C P_{i t}$ respectively. The second type is the number of $\mathrm{G}$ patents and collaborative patents which are applied for by firm $i$ in time $t$. We name these variables $K C G_{i t}$ and $K C P_{i t}$ respectively. This second type of variable is used to see the impact of

\footnotetext{
${ }^{17}$ Here, we focus on patents applied for by at least one firm but we include also the cases of collaboration of firms with universities and/or public research institutes.

${ }^{18}$ It is important to note that collaborative patents are a subset of collaborative R\&D, as not all R\&D activities lead to a patent application. Therefore, to analyze both types of collaboration at the same level, we use the number of patents generated by the participating firms in a consortium for estimating the impact of government-sponsored consortia, instead of the number of instances of actual participation. Using patents as an indicator of participation in public consortia is a much more restrictive way than using the number of actual incidents of participation and is very similar to our definition of privateled collaboration.

${ }^{19}$ These are actually the data commonly used as an indicator of the stock of knowledge. Thus, we assume that some of the knowledge becomes obsolete over time, which is a common assumption to measure the stock of knowledge, and that the depreciation (obsolescence) rate is $10 \%$ per year. In fact, we cannot identify the correct depreciation rate in RT fields, so we also conduct estimations in the cases of $20 \%$ depreciation rates and without a depreciation rate. The results are not affected by these changes.
} 
collaboration activities on the productivity of contemporary $R \& D$ activities. The equations to be estimated become:

$$
\begin{aligned}
& N_{i t}=\beta_{0}+\beta_{1} R_{i t}+\gamma_{0} K_{i t}+\beta_{2} P C G_{i t}+\beta_{3} P C P_{i t}+\beta_{4} S c_{i t}+\mu_{i t} \\
& N_{i t}=\beta_{0}+\beta_{1} R_{i t}+\gamma_{0} K_{i t}+\beta_{2} K C G_{i t}+\beta_{3} K C P_{i t}+\beta_{4} S c_{i t}+\mu_{i t}
\end{aligned}
$$

We also test if the collaborative R\&Ds increase research productivity through the spillover augmenting effects by estimating the following equations:

$$
\begin{aligned}
& N_{i t}=\beta_{0}+\beta_{1} R_{i t}+\gamma_{0} K_{i t}+\gamma_{1} K_{i t} * P C G_{i t}+\gamma_{2} K_{i t} * P C P_{i t}+\mu_{i t} \\
& N_{i t}=\beta_{0}+\beta_{1} R_{i t}+\gamma_{0} K_{i t}+\gamma_{1} K_{i t} * K C G_{i t}+\gamma_{2} K_{i t} * K C P_{i t}+\mu_{i t}
\end{aligned}
$$

The purpose of each empirical test is summarized as follows:

11-1: $\quad$ Test if past participation affects R\&D productivity

11-2: $\quad$ Test if current participation affects R\&D productivity

11-3: $\quad$ Test if past participation affects R\&D productivity through spillover effects

11-4: $\quad$ Test if current participation affects $R \& D$ productivity through spillover effects

\section{Results}

\subsection{Basic Statistics of G and NG Firms}

Table 2 shows the basic characteristics of patents applied for by firms that have participated in public projects (G firms) and firms that have never participated in public projects (Non-G firms). First, we note that the average number of patents per firm is much higher for $G$ firms than Non-G firms (152 against 29). The number of patents can be regarded as a measure of the scale of R\&D activities for RT by firm. Thus, the data show that $\mathrm{G}$ firms tend to have been involved in RT-related R\&D on a much larger scale than Non-G firms. Second, the average number of private-type collaborative patents is larger for $\mathrm{G}$ firms than Non-G firms (14 or 11, depending on the definition of G patents, against 4). This means that the participants in public projects tend to be more involved with collaborative R\&D outside of the public project than non-participants. It means also that there is no obvious substitution effect of private-led collaboration by collaborative-led collaboration for the G firms. 
Another important issue concerns the comparison of quality of patents for these two types of firms. In Table 3, five indicators of patent quality for $G$ and Non-G firms are summarized. The average number of each indicator is a little higher for $G$ firms than Non-G firms. To see if these indicators are statistically different between G firms and Non-G firms, we calculated two sample mean comparison tests. Whereas the numbers of forward and backward citations are not significantly different between the two types of firms, we find that the numbers of claims, inventors, and technological fields are statistically significantly higher for $G$ firms than Non-G firms at a $1 \%$ significance rate. This may indicate that the research productivity of $\mathrm{G}$ firms is intrinsically higher than that of Non-G firms. Thus, we cannot reject the possibility that firms with higher research productivity tend to be selected as participants in public projects. This may cause an endogeneity problem in our models, something that we will try to deal with in the following section (4.2).

$===$ Insert Table 3 around here $===$

We also conduct a $\chi$ square test which investigates whether the technological fields of patents applied for by G firms and Non-G firms differ. The data show that both groups have a similar tendency in patent applications in terms of technological fields. Therefore, there appears to be no problem using Non-G firms as a control group in terms of technological specialty.

\subsection{Effect of Participation on Research Productivity}

We first conduct an empirical analysis to test the hypothesis that an increase in the intensity of participation is associated with an increase in the productivity (or quality) of the firm's R\&D activities. The equation we estimate is based on (2) and is of the following form:

$$
N_{i t}=\beta_{0}+\beta_{1} R_{i t}+\beta_{2} C_{i t}+\beta_{3} S c_{i t}+\mu_{i t}
$$

where: 
$N_{i t}$ is the number of claims of patents generated by firm $i$ in time $t$;

$R$ is the number of inventors for the patent;

$C_{i t}$ is the accumulated number of consortia in which a firm $i$ has been involved before year $;^{20}$

$S c_{i t}$ is the number of patents in the "science based" technologies among the sub-types of RT technologies. We include this variable as a control variable as it seems to be related to the productivity of technology or the number of claims.

Table 4 presents the results of the estimations using fixed effects and random effects. As discussed earlier, the intensity of participation is likely to be correlated to the unobserved research quality of each firm. In this case, the random effects model is inconsistent and the fixed effects model, which controls unobserved time invariant effects, is more appropriate. In fact, this is confirmed by a simple Hausman specification test, which suggests that the random effect model is misspecified.

\section{$===$ Insert Table 4 around here $===$}

The results show that the term of intensity of participation $(C)$ is positive and statistically significant, indicating that the participation of an additional consortium in the past has a positive impact on the quality of the R\&D activity of firms. Using the coefficient estimated by the fixed model, the number of claims of patents generated by a firm in time $t$ increases on average by $2.3 \%(=$ $[\exp (0.1547)-1] \times 0.14)$ as a result of additional participation in the past. Obviously, this figure is not so large.

One thing we have to note is that there may be a sampling bias if we include non-participating firms into the dataset, as data do not show how great the magnitude of the impact would be if nonparticipants were involved with the projects. As there is a relatively large number of non-participating firms in the dataset, there are many cases where explanatory variables take a 0 value, and this may lead to the underevaluation of the impact of the explanatory variable. Therefore, we also estimate the same model using data which include only the participating firms in order to get more robustness for our

\footnotetext{
${ }^{20}$ Alternatively, accumulated years of participation in the consortia can be used as an explanatory variable, yet the conclusion is almost the same in this case, too. See Table A1 in Appendix 3.
} 
estimation. The results of this estimation are presented in Table A2 of Appendix 3. Here again, the results show that impact of participation in consortia has a positive and significant effect on research productivity. Moreover, in this case, the number of claims of patents generated by a firm in time $t$ increases on average by $13 \%$ as a result of additional participation in the past, which is a much larger figure than in the previous estimation (Table 4). ${ }^{21}$

As noted earlier, there may be a problem of endogeneity for $C_{i t}{ }^{22}$ The government decides which companies take part in which projects, and this assignment is not random. Governmental officials tend to select firms whose $R \& D$ productivities are high and who have participated in projects more frequently. In order to solve this problem and check the robustness of the model, we conduct 2SLS in the following way:

$$
\begin{gathered}
\widehat{C}_{i t}=\theta_{0}+\theta_{1} R_{i t}+\theta_{2} C P_{i t}+\theta_{3} S c_{i t}+\theta_{4} C_{i, t-k}+\sum \theta_{d} Y_{i d}+\varepsilon_{i t} \\
N_{i t}=\beta_{0}+\beta_{1} R_{i t}+\beta_{2} \widehat{C}_{i t}+\sum \theta_{d} Y_{i d}+w_{i t}
\end{gathered}
$$

where $R_{i t}$ and $S c_{i t}$, are the same definitions as before; $C P_{i t}$ is the frequency of collaboration with other firms for firm $i$ in time ;. $C_{i t-k}$ is the k-lagged values of $C_{i t}$; and $Y_{i t}$ is the year dummy variable.

We expect that the larger companies tend to participate in government-sponsored projects more often, and that if firms have more experience in collaborative $R \& D$ in the past, they tend to be more willing to take part in projects. Moreover, most of the targeted technologies of projects are science-based technologies, which are more closely related to next-generation robots. Thus, companies which have a higher ratio of science-based technologies related patents to total RT patents tend to participate in projects more often. Furthermore, concerning the k-lagged variable $C_{i t-k \text {, }}$, we suppose that there is some "bureaucratic" inertia in the selection process, as suggested in Branstetter and

\footnotetext{
${ }^{21}$ It is difficult to say more about this figure and to compare it more precisely to the former figure. Whether it is large or small depends on the R\&D activity of participating firms. For companies with many claims of patents, an increase of $13 \%$ in the number of claims as a result of additional participation is significant. However, for companies with a small number of claims, what they may expect to benefit from their participation in a government program may be considered relatively insignificant.

${ }^{22}$ We conduct a Hausman-Wu Test for the problem of endogeneity and the null hypothesis is rejected. This means that $C$, participation, appears to be endogenous to the model.
} 
Sakakibara [1998]. Firms which were frequently selected as participants in projects in the past are more likely to be selected in projects given their research quality. ${ }^{23}$

Table 5 reports the result of fixed effects IV estimation. In the table, column 1 gives the results of the first stage within regression. In this model, we include the lag 3 , lag 4 , and lag 5 variables of $C_{i t}$. The results show that the size of companies and the degree of science orientation in technology have a significant impact on intensity of participation, while the past experiences of collaborative $R \& D$ do not affect it.

\section{$===$ Insert Table 5 around here $===$}

The model of column 2 in Table 5 reports the results of 2SLS, which uses the results of the first stage 1. $C_{i t}$ has a significantly positive impact on quality-adjusted R\&D productivity. These results indicate that the intensity of participation affects $R \& D$ productivity, even after the model is adjusted to the endogeneity issue. ${ }^{24}$.

\subsection{Impact on the Spillover Effects}

We then conduct an empirical test to see if the impact of consortia on research productivity includes the augmentation of knowledge spillover effects. The equation we estimate is

$$
N_{i t}=\beta_{0}+\beta_{1} R_{i t}+\gamma_{0} K_{i t}+\gamma_{1} K_{i t} * C_{i t}+\beta_{2} S c_{i t}+\mu_{i t}
$$

which is based on (8). The coefficient of the interaction term, $K_{i t}{ }^{*} C_{i t}$, represents the magnitude of the change in innovation productivity elasticity to participation for a given level of potential knowledge

\footnotetext{
${ }^{23}$ If we exclude the variables $C P_{i t}$ and $S c_{i t}$, the results do not change.

${ }^{24}$ However, it should be noted that this result depends on the robustness of the results of estimation of the first stage, for which we concluded that the lag 3 , lag 4 , and lag 5 of $C_{i t}$ are exogenous to R\&D productivity. When longer lagged variables (e.g., from lag 6 to 8) are included in the first stage of the 2SLS model, we cannot conclude that the intensity of participation has a positive impact on R\&D productivity because the coefficient of $C_{i t}$ is no longer significant. We also estimated the same model using only the participants in projects as the sample. In this case, the result is almost same as in the previous case (but the coefficient of $C_{i t}$ is larger, about 31). However, if we take longer lagged variables (from 6) as instruments in this estimation, the coefficients of those variables in the first stage are not significant (or $10 \%$ significant). Thus, there may be a problem of weak instruments for these longer lagged variables and they are not appropriate as instruments. Finally, let us mention that we have three indicators to measure the intensity of participation, accumulated numbers of participated projects (C), accumulated years that the firm participated $(C Y)$, and the number of projects the firm participates in at time $t(C C)$. We also used CY and CC to estimate the 2SLS model. In the case where we use $C Y$, the result is almost the same as the case of using $C$. In the case where we use $C C$, the coefficient of $C C$ is positively significant if we take longer lagged variables (from 6) as instruments.
} 
spillovers. In other words, the coefficient measures the impact of participation on the absorptive capacity of a firm in terms of utilizing knowledge outside of the firm. ${ }^{25}$

The results in Table 6 show that the interaction term is positive and statistically significant, indicating that participation increases the knowledge spillovers. Here again, according to the Hausman specification test, the random effect model is not appropriate. However, we cannot see much difference in the coefficients between fixed and random models, thus the selection of estimation methods between them does not show bias in the estimation.

\section{$===$ Insert Table 6 around here $===$}

The results suggest that the impact of participation in consortia on research productivity includes the channel of raising the incoming spillovers of the participating firms. Using the coefficient estimated by the fixed model, the number of claims of patents generated by a firm in time $t$ increases on average by $1.6 \%(=[\exp (0.0002)-1] \times 80.76)$ as a result of additional participation in the past for a given potential spillover level. Here again, this number is apparently relatively small.

As in the case of research production function, we also estimate the same model using data which include only the participating firms to get more robustness for our estimation. The results of this estimation are presented in Table A4 of Appendix 3. The results indicate that participation in consortia has a positive and significant effect on research productivity through the knowledge spillover augmenting effects. The result shows that the number of claims of patents generated by a firm in time $t$ increases on average by $9.5 \%$ as a result of additional participation in the past, which is much larger than the results reported previously, in Table 6.

\subsection{Impact of the evolution of the program}

We have used the number of claims as an indicator to measure research productivity in the estimations so far. Another commonly used indicator for quality-adjusted R\&D productivity is the

25 We used the accumulated number of consortia for $K_{i t} * C_{i t}$. Alternatively, accumulated years of participation in the consortia $(C Y)$ can be used for variable $K_{i t}{ }^{*} C_{i t}$; the conclusion is almost the same. See Table A3 in Appendix 3 . We do not include $C i t$ as an explanatory variable for the observed existence of multicollinearity with the interaction term $K_{i t} * C_{i t}$. 
number of forward citations. We also estimated (12) and (14) using the number of forward citations as a dependent variable. Yet, in these cases, we cannot find any positive relation between intensity of participation and research productivity. This may, however, be due to the fact that the sample period for this estimation is only up to 1997 owing to the lack of data on forward citations. As discussed in Section 1.2, the design of government programs on RT changed dramatically in the late 1990s. The non-significant impact on forward citations may stem from the fact that the impact of participation was much lower before the late 1990s.

To further investigate this point and to check whether the impact of participation will differ as the design and goals of the government programs evolve, we estimate the following model:

$$
N_{i t}=\beta_{0}+\beta_{1} R_{i t}+\beta_{2} C_{i t} *(\text { from } X X)+\mu_{i t} \quad \text { with } \quad X X=94,95, \ldots 04
$$

where $N_{i t}$ is the number of claims; $C_{i t}$ is the number of consortia firm $i$ participated in in time $t$ (and not the accumulated number, as in the previous estimations). from $X X$ are year dummy variables, which take the value 1 after the year indicated in the name of variables.

The estimation result is reported in Table 7 . We find that the cross term of $C_{i t}$ and the dummy variables from $92 \ldots$ from 97 are insignificant or weakly significant. Yet the cross term of $C_{i t}$ and from 98 is significantly positive, indicating that the impact of participation on research productivity significantly differs before and after 1998. Also, we find that the participation terms with from $99 .$. from04 are positively significant at the $1 \%$ level. Thus, we can infer that participation in public projects began to have much more impact on research productivity after 1998.

The analysis above indicates that the impact of participation has changed after 1998, yet we cannot be certain in which year the change occurred. To examine the year of structural break, we conduct a Chow test based on the estimation results above. The results of the Chow test show that the chi-squared value in 2000 is the highest $(87.42, \mathrm{P}>$ chi2 $=0.000)$, indicating that the structural break occurred in 2000 .

$===$ Insert Table 7 around here $===$ 
These results suggest that the impact of participation on research productivity is significantly higher in the latter part of the sample period, and the structural break is likely to have happened around 2000. We reported that there is no impact of participation on the number of forward citations, whereas there is a positive impact on the number of claims. The difference in these results is likely to stem from the fact that the sample period for the model with forward citations is only up to 1997 and the impact of participation on research productivity is quite small up to the late 1990s. As mentioned earlier, it corresponds to the time when the policy of METI became more articulated and focused on research in RT in order to create a new market for service robots. The HRP project, the first comprehensive project, started in 1998. The themes of subsequent projects were organized on the basis of a clearer strategy regarding the development of the industry. Although these results should be interpreted cautiously, the difference in the effects on research productivity before and after this time appears to stem from these changes in the nature of the projects and the involvement of METI.

\subsection{Government-Coordinated Consortium and Market-Coordinated Collaborative Research}

As discussed earlier, government-sponsored consortia can be thought as one kind of collaborative research. In this section, we estimate and compare the impact of both government-sponsored consortia (or government-coordinated collaboration) and collaborative research among firms (or marketcoordinated collaboration) on research productivity.

For this purpose, we estimate the following equations which are the empirical versions of equations (11-1) to (11-4):

$$
\begin{aligned}
& N_{i t}=\beta_{0}+\beta_{1} R_{i t}+\gamma_{0} K_{i t}+\beta_{2} P C G_{i t}+\beta_{3} P C P_{i t}+\beta_{4} S c_{i t}+\mu_{i t} \\
& N_{i t}=\beta_{0}+\beta_{1} R_{i t}+\gamma_{0} K_{i t}+\beta_{2} K C G_{i t}+\beta_{3} K C P_{i t}+\beta_{4} S c_{i t}+\mu_{i t} \\
& N_{i t}=\beta_{0}+\beta_{1} R_{i t}+\gamma_{0} K_{i t}+\gamma_{1} K_{i t} * P C G_{i t}+\gamma_{2} K_{i t} * P C P_{i t}+\mu_{i t} \\
& N_{i t}=\beta_{0}+\beta_{1} R_{i t}+\gamma_{0} K_{i t}+\gamma_{1} K_{i t} * K C G_{i t}+\gamma_{2} K_{i t} * K C P_{i t}+\mu_{i t}
\end{aligned}
$$

where: 
$P C G_{i t}=$ the accumulated number of G1 patents for firm $i$ applied before time $t$ with a depreciation rate of $10 \%$.

$P C P_{i t}=$ the accumulated number of collaborative patents for firm $i$ applied before time $t$ with a depreciation rate of $10 \%$.

$K C G_{i t}=$ the number of $\mathrm{G} 1$ patents for firm $i$ in time $t$

$K C P_{i t}=$ the number of collaborative patents by two or more firms for firm $i$ in time $t$

The estimation results are presented in Table 8, and statistical implications based on the estimations are summarized in Table 9. For all the estimations, the Hausman specification test suggests that the random effect models are not appropriate, so we only present the results of fixed effects models. The results show that the variables which are related to participation in government projects are positive and significant for all the models. This implies that participation in public projects both in the present and in the past positively affects the quality of patents, and one channel of impact is the spillover augmenting effects.

\section{$===$ Insert Tables $8 \& 9$ around here $===$}

On the other hand, market-coordinated collaboration appears to have a significant impact on the quality-adjusted productivity of firms only in the case of contemporary R\&D activities, as past experiences of collaboration do not affect the productivity of research. ${ }^{26}$ Moreover, there is no evidence of spillover augmenting effects. ${ }^{27}$

In the estimation above, G1 patents are used to define the variables. We also estimated the same model with the G2 definition and found that the statistical implication is not different from the models with G1 patents. These results indicate that the impact of market-coordinated collaborative

\footnotetext{
${ }^{26}$ This result is basically consistent with the findings of Lechevalier et al. (2007), who find evidence of a positive impact of current market-coordinated collaborative R\&D on the quality of patents, but cannot find any evidence of a positive impact of past collaborative $R \& D$ in this case.

${ }_{27}$ As in the previous cases, we also estimate the same models using data which include only firms participating in government programs to achieve greater robustness for our estimation. The results are summarized in Table A5 of Appendix 4. Some of the variables we found previously significant become insignificant. The variables that are related to collaborative patents are insignificant in all the models, indicating that there is no impact of market-coordinated collaboration on research productivity in any way. Also, participation in public projects in the past seems not to affect research productivity, whereas current involvement still has an impact on it.
} 
research on research productivity is relatively limited compared to the government-coordinated collaboration. It is possible to think of several potential reasons for the observed difference in the impact between the two types of collaborative research.

First, government tends to pick up R\&D themes which are closer to the technological frontier, and the goals of government projects tend to be quite ambitious. As shown in Appendix 1, the themes of public projects are very general, and the effects of such research tend to extend to the whole of an industry or society. This kind of research is likely to generate significant spillover effects but is often inappropriate to the $\mathrm{R} \& \mathrm{D}$ of private firms, as it tends to benefit to other firms. Also, as shown in Table 1 , the target technologies of public projects tend to be more science-based technologies, such as mobile robots, control of mobile robots, and image processing rather than other R\&D. The R\&D projects on science-based technologies are potentially more risky, even though the benefits and learning effects tend to be bigger. It is often difficult for firms to undertake a highly risky R\&D, but the firms may be able to engage in risky $R \& D$ if it is a public project, as the publicly sponsored projects signal future demand and increase the expected return on R\&D investment (the PumpPriming effect). Also, the public funds expended on the projects will decrease the firms' costs for $\mathrm{R} \& \mathrm{D}$ and increase their incentive to participate (Cost Sharing).

Second, as participation in public projects goes with an ex ante agreement on the ownership of research output, there is less risk of opportunistic behavior and necessity of bargaining over the research outcome. Having monitoring and evaluation by a public institution also promotes cooperation among the participants. Accordingly, the participants can be more eager to collaborate with other participants, which will promote knowledge sharing and more knowledge spillovers (institutionalbuilding trust). In the case of RT-related public projects, special committees whose members include external personnel were usually formed to specify research plans and organizations, monitor the R\&D, and conduct project appraisals. For example, the plan of the HRP project was decided by the HRP Development Promotion Committee. The HRP Technology Committee and HRP Research Committee monitored the research of the project. These monitoring mechanisms are thought to promote trust and knowledge sharing among participants. 
Third, the difference in relative scale of research between the two types of collaboration we distinguished might have affected their respective impacts. As shown in Appendix 1, a relatively large number of firms participate in public projects, whereas $R \& D$ collaboration among firms is typically undertaken by only two partners in most cases. If the number of participating firms is larger, the accumulated level of knowledge of the participants is likely to be larger, and there are more chances for each participating firm to access complementary technology; thus, the spillover effects tend to be larger.

Finally, government involvement may have decreased the coordination costs which were necessary to form R\&D collaboration. The coordination costs include the search costs to find a proper partner, the cost of negotiations on the allocation of the research results, and the management costs for the projects. The interviews we conducted with a number of related firms indicate the existence of such coordination costs. Most of the interviewees claim that "there is less collaboration in $R \& D$ among firms than there should be," and that one reason for this is that "the negotiations for the collaboration, especially on the allocation of research results, are troublesome tasks." One interviewee points out that collaboration among firms tends to be easier when the government or a large firm is taking a lead in negotiation. As these coordination costs will become larger as the number of participants becomes larger, the government might have played the role of coordinator, bearing these costs and helping to realize larger scale $R \& D$ collaboration that cannot be undertaken by the coordination by markets.

\section{Conclusion}

In this article, we have proposed an evaluation of government-supported R\&D consortia in Japan based on the methodology developed by Sakakibara \& Branstetter (1998). We have focused on the case of robot technology, which has rarely been an object of analysis from this point of view. Our main methodological contribution is the use of indicators of the quality of patents (numbers of claims and citations) instead of number of patents as indicators of the outcomes of the programs. This allows us to provide an estimation of quality-adjusted research productivity. 
Our findings can be summarized as follows. First, participation in government-sponsored $R \& D$ consortia tends to lead to an increase in the research productivity of participating firms. Yet the clear impact of consortia on research productivity seems to begin to appear after the late 1990s, when the nature and design of METI's programs changed towards a more comprehensive and systematic view of the RT field. Second, the channel through which the consortia affect research productivity includes the increase in incoming spillovers, or a firm's absorptive capacity to utilize the knowledge outside of the firm. Third, if we divide collaborative R\&D into government-coordinated collaboration and market-coordinated collaboration, the latter appears to have a limited impact on research productivity, whereas the former seem to have a non-negligible impact.

Finally, this study can be complemented by further research especially regarding the following points. At a general level, it is important to check whether our main result - the positive impact of participation in government consortia on R\&D productivity - comes from the characteristics of the robot technology or industry. The positive impact of government coordination on private R\&D may result from the nature of robot technology - which requires a high level of collaboration as an assembling technology - as well as the current state of the industry, which is characterized by a high degree of uncertainty. At a more specific level, it is necessary to provide more direct tests of whether government-led collaboration is complementary to or a substitute for market-led collaboration. In this paper, we only conducted an indirect test by comparing these two types of collaboration. The significant impact of participation in government consortia may not be enough to justify government participation in this field. 


\section{References}

Branstetter, L. G. and Sakakibara, M. (2002). When Do Research Consortia Work Well and Why? Evidence from Japanese Panel Data. The American Economic Review, 92, 1, pp. 143-159, March.

Branstetter, L. G. and Sakakibara, M. (1998). Japanese Research Consortia: a Microeconometric Analysis of Industrial Policy. The Journal of Industrial Economics, 46-2, June.

Das, T. K., and Teng B.S. (1998). Between trust and control: Developing confidence in partner cooperation in alliances. Academy of Management Review, 23(3), 491-512.

David, P., Hall, B. H. and Toole, A. A. (2000). Is public RandD complement or substitute for private RandD? A review of the econometric evidence. Research Policy, 29, 497-529.

Darby, M.R., Zucker, L.G. and Wang, A. (2003). Universities, joint ventures and success in the advanced technology program, NBER Working Paper Series 9463.

Goto, A., Genba, K., Suzuki, J. and Tamada S. (2006). Indicators for identifying important patents, RIETI Discussion Paper Series 06-J-018 (in Japanese).

Guellec D. and van Pottelsberghe de la Potterie B. (2003). The impact of public RandD expenditure on Business RandD, Economics of Innovation and New Technology, 12(3), 225-243.

Hagedoorn, J., Link, A. N. and Vonortas, N. S. (2000). Research partnerships. Research Policy, 29, $567-586$.

Jaffe, B.A. (1986). Technological opportunity and spillovers of RandD: Evidence from firms' patents, profits, and market value. The American Economic Review, 76 (5), 984-1001.

Jaffe, B.A. and Trajtenberg, M. (2002). Patents, Citations and Innovations A window on the knowledge economy. The MIT Press.

JPO (2002). Robotto ni kansuru tokkyo shutugan gijutu doukou chousa.

Katz, M.L. (1986). An Analysis of Cooperative Research and Development. Rand Journal of Economic, 27, 527-543.

Kondo, M. (1990). Japanese R\&D in robotics and genetic engineering, in Sigurdson, J. (ed.). Measuring the Dynamics of Technological Change. Cassell and Co. 
Lechevalier, S., Ikeda, Y. and Nishimura, J. (2007). Investigating Collaborative R\&D Using Patent Data: The Case Study of Robot Technology in Japan, IER Discussion paper Series, A No-498, Hitotsubashi University.

Lechevalier, S., Ikeda, Y. and Nishimura, J. (2006). Collaborative R\&D in the robot technology in Japan: an inquiry based on patent data analysis (1991-2004), CIRJE Discussion Paper Series, No. 2006-37.

METI. (2005a). New industries creation strategy (in Japanese).

METI. (2005b). Robot Seisaku Kenkyukai Chukan Hokokusho-Robot de hiraku Business Frontier.

Motohashi, K. (2003). Recent Development in Research and Innovation Policy in Japan, Institute of Innovation Research Working Paper, \#03-03, Hitotsubashi University

Odagiri, H., Nakamura, Y. and Shibuya, M. (1997). Research Consortia as a vehicle for basic research: the case of the fifth generation computer project in Japan. Research Policy, 26, 191-207.

Okada, Y., Nakamura, K. and Tohei, A (2006). Is There a Significant Contribution of Public Sector in Biomedical Research in Japan? A Detailed Analysis of Government and University Patenting, 1991-2002, COE-RES Discussion Paper Series, No.175.

Okada, Y., Okino, I. and Narita, Y. (2003). Nihon no Bio-Venture ni okeru Kyodo kenkyu to tokkyo shutugan, in Goto, A. and Nagaoka, S. (ed.) Chiteki zaisan seido to Innovation. Tokyo University Press, pp.167-196.

Okada, Y. and Kushi, T. (2004). Government-Sponsored cooperative research in Japan: A case study of the Organizational for Pharmaceutical Safety and Research (OPSR Program, OPIR Research Paper Series, No.22.

Spence, M.A. (1984). Cost Reduction, Competition, and Industry Performance. Econometrica, 52, $101-121$

Wooldridge, J.M. (2002). Econometric Analysis of Cross Section and Panel Data. The MIT Press Cambridge.

Zucker, L. G. and Darby, M. R. (1996). Star scientists and institutional transformation: Patterns of invention and innovation in the formation of the biotechnology industry, Proceedings of the National Academy of Sciences, 93(23), 12,709-12,716. 


\section{Figures \& tables}

\section{Figure 1: $21^{\text {st }}$ Century Robot Challenge Program and Action Plan (NICS) - History, Linkage and Hierarchy of the Public Policy by METI}

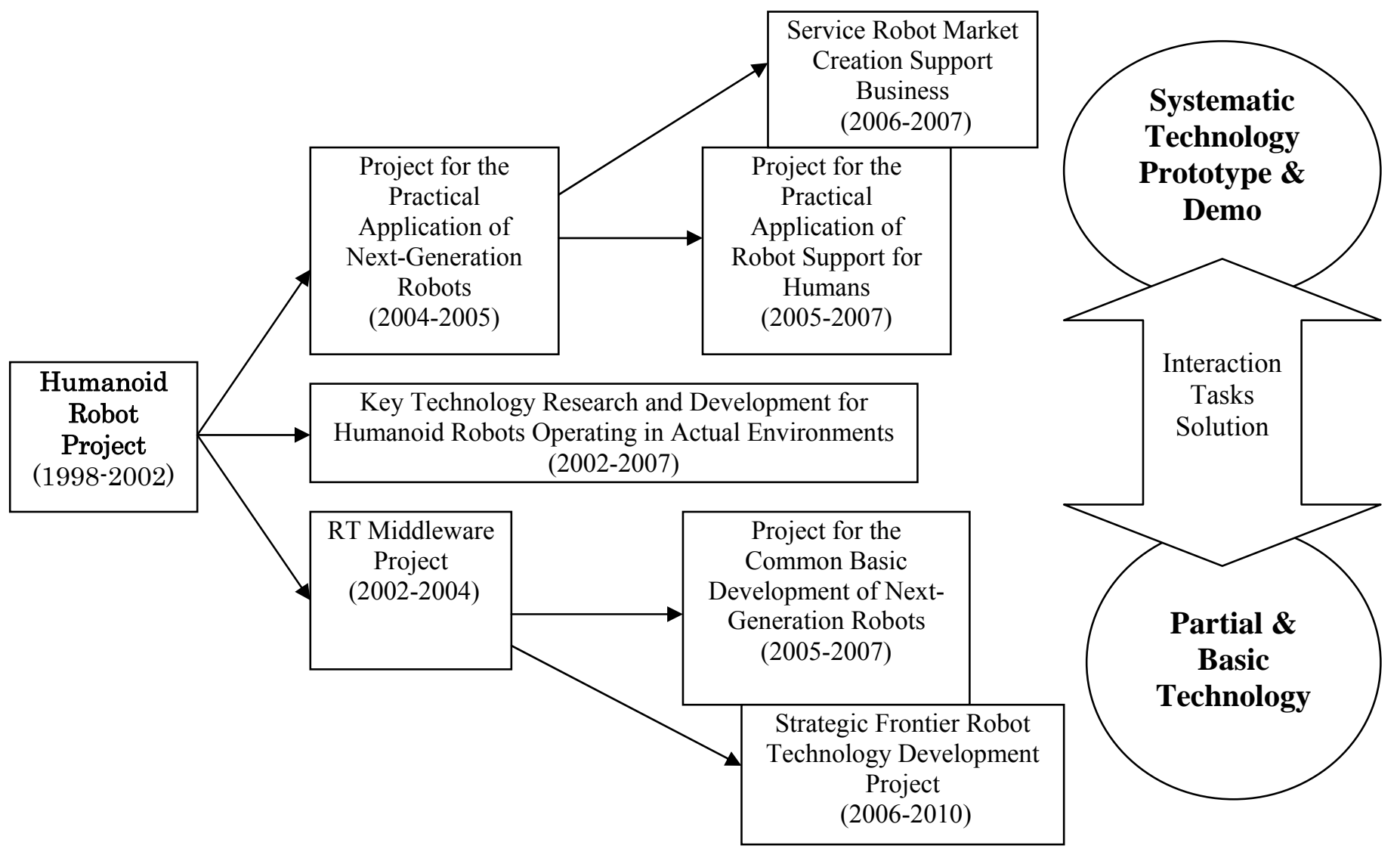

Source : METI (2005a,b) 
Figure 2: Four macro-classifications and 20 micro-classifications of RT

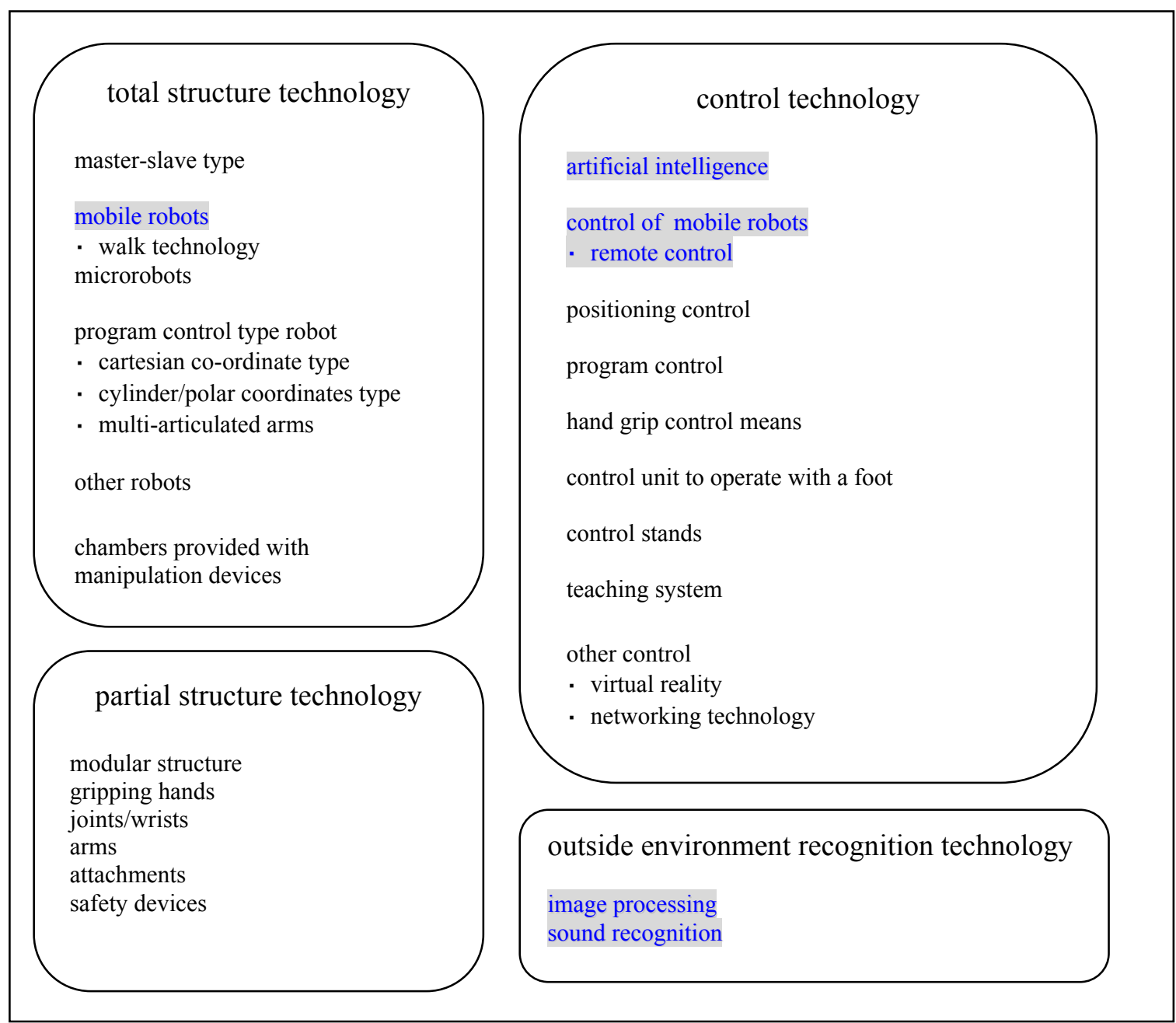

Source: JPO (2002)

Note: The technologies shaded are closely related to the technology of next-generation robots 
Table (1) The distribution of G1 patents by 12 public projects and 20 micro-technological fields (percentage)

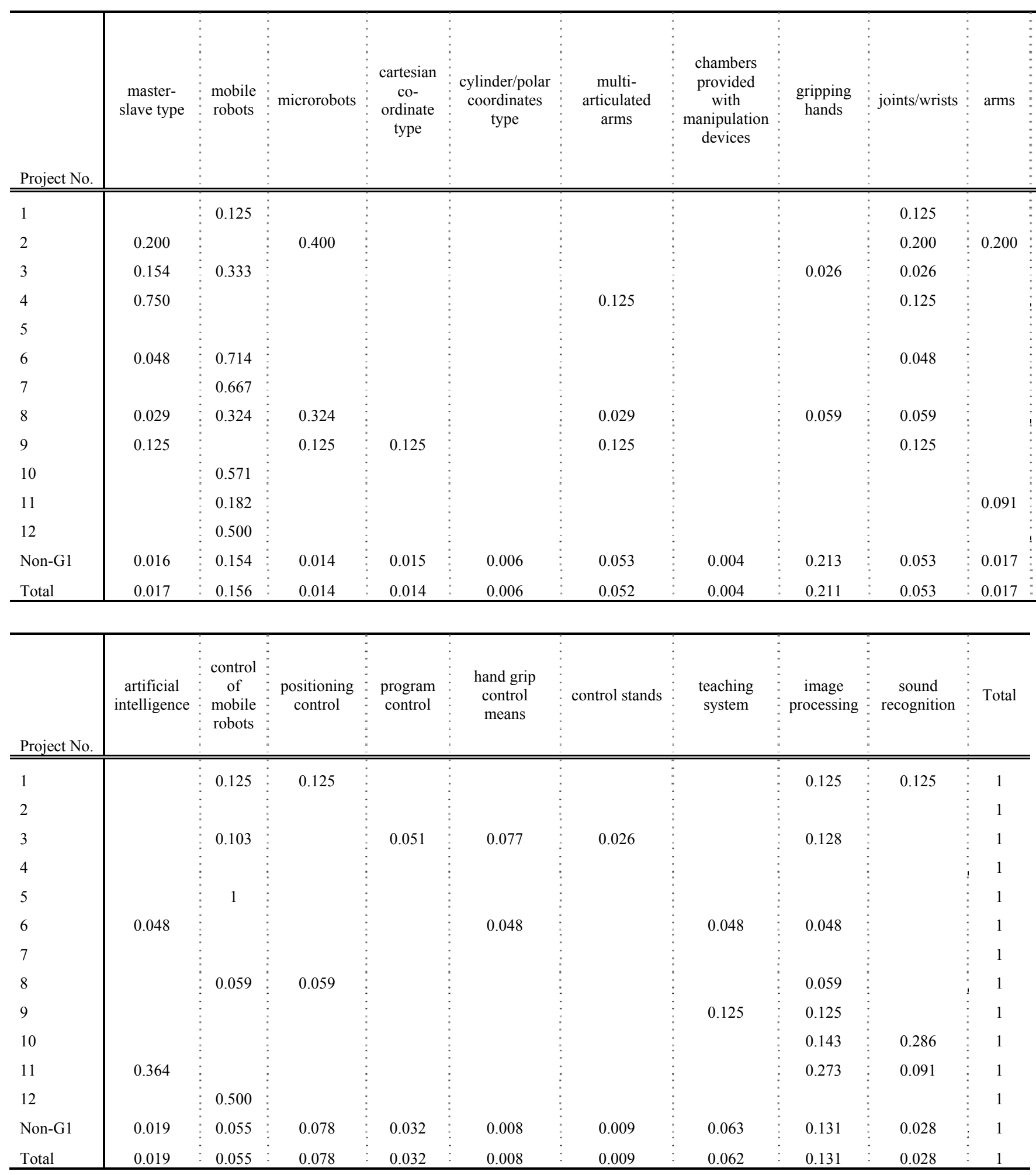

Note: For the definition of the 12 public projects, see Appendix 1. 
Table (2): Basic Characteristics of G Firms \& Non-G Firms

\begin{tabular}{|c|c|c|c|}
\hline Firm Types & & Total & $\begin{array}{l}\text { Average } \\
\text { per firm }\end{array}$ \\
\hline \multirow{10}{*}{$\begin{array}{l}\text { G Firms } \\
\text { (36 firms) }\end{array}$} & Trend of patents & & \\
\hline & Total RT patents & 5488 & 152.444 \\
\hline & G1 patents & 94 & 2.611 \\
\hline & G patents (G1 or G2 patents) & 1281 & 35.583 \\
\hline & Collaborative patents (exc.G1 patents) & 528 & 14.667 \\
\hline & Collaborative patents (exc.G patents) & 419 & 11.639 \\
\hline & $\%$ of collaborative patents (exc.G patents) & 7.635 & - \\
\hline & Trend of Participation in Projects & & \\
\hline & Frequency_n (Numbers of projects) & 327 & 9.083 \\
\hline & Frequency_y (Years of projects) & 1632 & 45.333 \\
\hline \multirow{4}{*}{$\begin{array}{l}\text { Non-G Firms } \\
\text { (280 firms) }\end{array}$} & Trend of patents & & \\
\hline & Total RT patents & 8223 & 29.368 \\
\hline & Collaborative patents & 1186 & 4.236 \\
\hline & $\%$ of collaborative patents & 14.423 & - \\
\hline
\end{tabular}

Note: for the definition of G1 patents and G2 patents, refer to Section 2.2 and Appendix 2.

Table (3): R\&D Productivity in terms of Quality of Patents -Comparison between G Firms \& Non-G Firms

\begin{tabular}{|c|c|c|c|c|}
\hline Firm Types & & Total & Average & $\mathrm{SE}$ \\
\hline \multirow{8}{*}{$\begin{array}{l}\text { G Firms } \\
\text { (36 firms) }\end{array}$} & Total RT patents & 5488 & & \\
\hline & & & & \\
\hline & Quality per patent & & & \\
\hline & Claims & 5.599 & $5.803 * * *$ & 0.221 \\
\hline & Forward Citations & 0.509 & 0.511 & 0.041 \\
\hline & Backward Citations & 1.199 & 1.217 & 1.199 \\
\hline & The number of Inventors & 2.473 & $2.478 * * *$ & 0.080 \\
\hline & The number of Technological Fields & 1.397 & $1.353 * * *$ & 0.017 \\
\hline \multirow{8}{*}{$\begin{array}{l}\text { Non-G Firms } \\
\text { (280 firms) }\end{array}$} & Total RT patents & 8223 & 8223 & 8223 \\
\hline & & & & \\
\hline & Quality per patent & & & \\
\hline & Claims & 5.411 & 4.636 & 0.085 \\
\hline & Forward Citations & 0.450 & 0.480 & 0.029 \\
\hline & Backward Citations & 1.137 & 1.122 & 0.043 \\
\hline & The number of Inventors & 2.163 & 2.177 & 0.029 \\
\hline & The number of Technological Fields & 1.315 & 1.246 & 0.009 \\
\hline
\end{tabular}


Table (4) : Estimation of Research Productivity Function

\begin{tabular}{|l|c|c|}
\hline \multirow{2}{*}{ Variable } & \multicolumn{2}{|c|}{$\begin{array}{c}\text { Dependent variable: } \\
N \text { (number of claims) }\end{array}$} \\
\cline { 2 - 3 } & Fixed Effects & Random Effects \\
\hline$R$ & $\begin{array}{c}0.0102^{* * *} \\
(0.0003)\end{array}$ & $\begin{array}{c}0.0106^{* * *} \\
(0.0003)\end{array}$ \\
\hline S & $\begin{array}{l}0.1547^{* * *} \\
(0.0368)\end{array}$ & $\begin{array}{c}0.1860^{* * *} \\
(0.0335)\end{array}$ \\
\hline Sc & $\begin{array}{c}0.0483 \\
(0.0482)\end{array}$ & $\begin{array}{c}0.0824 \\
(0.0451)\end{array}$ \\
\hline Year Dummies & $\begin{array}{l}0.0802 \\
(0.0801)\end{array}$ & $\begin{array}{c}0.0647 \\
(0.0797)\end{array}$ \\
\hline Number of samples & yes & yes \\
\hline Number of groups & 2324 & 2329 \\
\hline Log likelihood & 311 & 316 \\
\hline Hausman Specification & chi2(16)= & Prob>chi2 $=0.0000$ \\
test & 75.37 & -8760.8442 \\
\hline
\end{tabular}

Note 1: *,**, ***: respectively significant at the $10 \%, 5 \%$, and $1 \%$ levels

Note 2: Standard errors in parentheses 
Table (5) : Fixed Effects IV Estimation

\begin{tabular}{|c|c|c|}
\hline & $C$ & $\begin{array}{c}N \text { (number of } \\
\text { claims) }\end{array}$ \\
\hline & 1 & 2 \\
\hline & coefficients & coefficients \\
\hline & standard errors & standard errors \\
\hline C & & $\begin{array}{c}22.5252^{* * *} \\
(8.2094) \\
\end{array}$ \\
\hline$R$ & $\begin{array}{l}0.001 * * * \\
(0.0003) \\
\end{array}$ & $\begin{array}{c}3.7101 * * * \\
(0.0665) \\
\end{array}$ \\
\hline$C P$ & $\begin{array}{l}0.0019 \\
(0.002) \\
\end{array}$ & \\
\hline Sc & $\begin{array}{c}0.0378^{* *} \\
(0.019) \\
\end{array}$ & \\
\hline$C(\operatorname{lag} 3)$ & $\begin{array}{c}0.3826 * * * \\
(0.0436) \\
\end{array}$ & \\
\hline$C(\operatorname{lag} 4)$ & $\begin{array}{c}0.2198 * * * \\
(0.0553) \\
\end{array}$ & \\
\hline$C(\operatorname{lag} 5)$ & $\begin{array}{c}0.2118^{* * *} \\
(0.0367) \\
\end{array}$ & \\
\hline constant & $\begin{array}{l}0.0300 * \\
(0.0159) \\
\end{array}$ & $\begin{array}{c}-12.4379^{* * *} \\
(4.0488) \\
\end{array}$ \\
\hline year dummies & yes & yes \\
\hline Number of samples & 1450 & 1450 \\
\hline Number of groups & 301 & 301 \\
\hline \multicolumn{3}{|l|}{ R. sq } \\
\hline Within & 0.4242 & 0.7428 \\
\hline Between & 0.9147 & 0.7378 \\
\hline Overall & 0.8614 & 0.7452 \\
\hline
\end{tabular}

Note 1: ***, ***: respectively significant at the $10 \%, 5 \%$, and $1 \%$ levels

Note 2: Standard errors in parentheses

Note 3: Model 1 is the first-stage within regression. In Model 2, the instrumented variable is $C$ and instrument variables are inventors, CP, Sc, C(lag3), C(lag4), C(lag5) and year dummy variables 
Table (6) : Estimation of Spillovers Model

\begin{tabular}{|l|c|c|}
\hline \multirow{2}{*}{ Variable Names } & \multicolumn{2}{|c|}{$\begin{array}{c}\text { Dependent variable: } \\
N \text { (number of claims) }\end{array}$} \\
\cline { 2 - 3 }$K$ & Fixed Effects & Random Effects \\
\hline$K$ & $0.0101^{* * *}$ & $0.0105^{* * *}$ \\
& $(0.0003)$ & $(0.0003)$ \\
$K * C$ & $0.0007^{* * *}$ & $0.0008^{* * *}$ \\
& $(0.0002)$ & $(0.0003)$ \\
$S c$ & $0.0002^{* * *}$ & $0.0003^{* * *}$ \\
& $(0.0001)$ & $(0.00006)$ \\
Constant & 0.0523 & 0.0821 \\
& $(0.0479)$ & $(0.0448)$ \\
Year dummies & $-0.1945^{*}$ & $-0.2279^{* *}$ \\
\hline Number of samples & $(0.117)$ & $(0.1069)$ \\
Number of groups & yes & yes \\
Log likelihood & 2324 & 2329 \\
\hline Hausman Specification test & 311 & 316 \\
\hline
\end{tabular}

Note 1: *,**, ***: respectively significant at the $10 \%, 5 \%$, and $1 \%$ levels Note 2: Standard errors in parentheses 
Table (7): Estimation of Structural Change

\begin{tabular}{|c|c|c|c|c|c|c|c|c|}
\hline & $\begin{array}{c}\text { Fixed effect } \\
\text { Dependen } \\
\text { (1) }\end{array}$ & $\begin{array}{l}\text { negative bi } \\
\text { variable: } N \\
\text { (2) }\end{array}$ & $\begin{array}{l}\text { hial regressio } \\
\text { er of claims } \\
\text { (3) }\end{array}$ & (4) & (5) & (6) & (7) & (8) \\
\hline$R$ & $\begin{array}{c}0.0089^{* * *} \\
(0.0005)\end{array}$ & $\begin{array}{c}0.0089^{* * *} \\
(0.0005)\end{array}$ & $\begin{array}{c}0.0089 * * * \\
(0.0005)\end{array}$ & $\begin{array}{c}0.0089 * * * \\
(0.0005)\end{array}$ & $\begin{array}{c}0.0089 * * * \\
(0.0005)\end{array}$ & $\begin{array}{c}0.0089 * * * \\
(0.0005)\end{array}$ & $\begin{array}{c}0.0089 * * * \\
(0.0005)\end{array}$ & $\begin{array}{c}0.0090 * * * \\
(0.0005)\end{array}$ \\
\hline$K$ & $\begin{array}{c}0.0007 * * \\
(0.0002)\end{array}$ & $\begin{array}{c}0.0007 * * \\
(0.0002)\end{array}$ & $\begin{array}{c}0.0007 * * \\
(0.0002)\end{array}$ & $\begin{array}{c}0.0007 * * \\
(0.0002)\end{array}$ & $\begin{array}{c}0.0007 * * \\
(0.0002)\end{array}$ & $\begin{array}{c}0.0007 * * \\
(0.0002)\end{array}$ & $\begin{array}{c}0.0008 * * * \\
(0.0002)\end{array}$ & $\begin{array}{c}0.0008 * * * \\
(0.0002)\end{array}$ \\
\hline$C$ & $\begin{array}{l}0.0986^{*} \\
(0.0444)\end{array}$ & $\begin{array}{c}0.3028 \\
(0.1902)\end{array}$ & $\begin{array}{c}0.1271 \\
(0.1283)\end{array}$ & $\begin{array}{c}0.0616 \\
(0.1047)\end{array}$ & $\begin{array}{c}0.0891 \\
(0.0901)\end{array}$ & $\begin{array}{c}0.0028 \\
(0.0742)\end{array}$ & $\begin{array}{l}-0.0006 \\
(0.0684)\end{array}$ & $\begin{array}{l}-0.0239 \\
(0.0625)\end{array}$ \\
\hline$K C G$ & $\begin{array}{c}0.0198^{* * *} \\
(0.0036)\end{array}$ & $\begin{array}{c}0.0201^{* * *} \\
(0.0036)\end{array}$ & $\begin{array}{c}0.0198^{* * *} \\
(0.0036)\end{array}$ & $\begin{array}{c}0.0198^{* * *} \\
(0.0036)\end{array}$ & $\begin{array}{c}0.0198 * * * \\
(0.0036)\end{array}$ & $\begin{array}{c}0.0189 * * * \\
(0.0037)\end{array}$ & $\begin{array}{c}0.0186^{* * *} \\
(0.0037)\end{array}$ & $\begin{array}{c}0.0199 * * * \\
(0.0036)\end{array}$ \\
\hline$K C P$ & $\begin{array}{c}0.0197 * * \\
(0.0067)\end{array}$ & $\begin{array}{c}0.0198 * * \\
(0.0067)\end{array}$ & $\begin{array}{c}0.0197 * * \\
(0.0067)\end{array}$ & $\begin{array}{c}0.0198^{* *} \\
(0.0067)\end{array}$ & $\begin{array}{c}0.0198 * * \\
(0.0067)\end{array}$ & $\begin{array}{c}0.0221 * * \\
(0.0067)\end{array}$ & $\begin{array}{c}0.0222 * * * \\
(0.0067)\end{array}$ & $\begin{array}{c}0.0221^{* * *} \\
(0.0066)\end{array}$ \\
\hline$S c$ & $\begin{array}{c}0.0613 \\
(0.0476)\end{array}$ & $\begin{array}{c}0.0625 \\
(0.0476)\end{array}$ & $\begin{array}{c}0.0613 \\
(0.0476)\end{array}$ & $\begin{array}{c}0.0611 \\
(0.0476)\end{array}$ & $\begin{array}{c}0.0611 \\
(0.0476)\end{array}$ & $\begin{array}{c}0.0584 \\
(0.0477)\end{array}$ & $\begin{array}{c}0.059 \\
(0.0476)\end{array}$ & $\begin{array}{c}0.0558 \\
(0.0477)\end{array}$ \\
\hline$C \times$ from 92 & & $\begin{array}{l}-0.2055 \\
(0.1867)\end{array}$ & & & & & & \\
\hline$C \times$ from 93 & & & $\begin{array}{l}-0.0287 \\
(0.1215)\end{array}$ & & & & & \\
\hline$C \times$ from 94 & & & & $\begin{array}{c}0.0373 \\
(0.0954)\end{array}$ & & & & \\
\hline$C \times$ from 95 & & & & & $\begin{array}{c}0.0095 \\
(0.0784)\end{array}$ & & & \\
\hline$C \times$ from 96 & & & & & & $\begin{array}{c}0.1072 \\
(0.0655)\end{array}$ & & \\
\hline$C \times$ from 97 & & & & & & & $\begin{array}{l}0.1192 * \\
(0.0611)\end{array}$ & \\
\hline$C \times$ from 98 & & & & & & & & $\begin{array}{c}0.1605^{* * *} \\
(0.056)\end{array}$ \\
\hline constant & $\begin{array}{l}-0.1796 \\
(0.1162)\end{array}$ & $\begin{array}{l}-0.2155 \\
(0.1217)\end{array}$ & $\begin{array}{l}-0.1834 \\
(0.1173)\end{array}$ & $\begin{array}{l}-0.1762 \\
(0.1166)\end{array}$ & $\begin{array}{l}-0.1791 \\
(0.1163)\end{array}$ & $\begin{array}{l}-0.1864 \\
(0.1163)\end{array}$ & $\begin{array}{c}-0.191 \\
(0.1164)\end{array}$ & $\begin{array}{l}-0.1955 \\
(0.1163)\end{array}$ \\
\hline Year dummies & yes & yes & yes & yes & yes & yes & yes & yes \\
\hline Number of samples & 2324 & 2324 & 2324 & 2324 & 2324 & 2324 & 2324 & 2324 \\
\hline Number of groups & 311 & 311 & 311 & 311 & 311 & 311 & 311 & 311 \\
\hline Log likelihood & -6982.7713 & -6982.2068 & -6982.7436 & -6982.6941 & -6982.7639 & -6981.3925 & $5-6980.8151$ & $1-6978.5485$ \\
\hline
\end{tabular}

Note $1: * * *, * * *$ : respectively significant at the $10 \%, 5 \%$, and $1 \%$ levels

Note 2: Standard errors in parentheses

Note 3: $\mathrm{C} \times$ from $99 \sim$ from04 are also positively significant at the $1 \%$ level. We omit those results to save space. 
Table (8): Comparison between the impact of market-coordinated collaboration and government-led collaboration. Fixed Effects Negative Binomial Regression

\begin{tabular}{|c|c|c|c|c|}
\hline & \multicolumn{4}{|c|}{ Dependent variable: $N$ (number of claims) } \\
\hline & $\mathrm{X} 1$ & $\mathrm{X} 2$ & $\mathrm{X} 3$ & $\mathrm{X} 4$ \\
\hline$R$ & $\begin{array}{l}0.0101 * * * \\
(0.0004)\end{array}$ & $\begin{array}{l}0.0094 * * * \\
(0.0004)\end{array}$ & $\begin{array}{l}0.0101 * * * \\
(0.0004)\end{array}$ & $\begin{array}{l}0.0097 * * * \\
(0.0004)\end{array}$ \\
\hline$K$ & $\begin{array}{l}0.0008 * * * \\
(0.0002)\end{array}$ & $\begin{array}{l}0.0008 * * * \\
(0.0002)\end{array}$ & $\begin{array}{l}0.0008 * * * \\
(0.0002)\end{array}$ & $\begin{array}{l}0.0007 * * * \\
(0.0002)\end{array}$ \\
\hline$P C G$ & $\begin{array}{l}0.0449^{* * *} \\
(0.0205)\end{array}$ & & & \\
\hline$P C P$ & $\begin{array}{l}-0.0004 \\
(0.0035)\end{array}$ & & & \\
\hline$K C G$ & & $\begin{array}{l}0.1062 * * * \\
(0.0211)\end{array}$ & & \\
\hline$K C P$ & & $\begin{array}{l}0.0171 * \\
(0.0066) \\
\end{array}$ & & \\
\hline$K * P C G$ & & & $\begin{array}{c}0.00008^{* * *} \\
(0.00003)\end{array}$ & \\
\hline$K * P C P$ & & & $\begin{array}{c}0.0000 \\
(0.0000)\end{array}$ & \\
\hline$K * K C G$ & & & & $\begin{array}{l}0.0002 * * * \\
(0.00005)\end{array}$ \\
\hline$K^{*} K C P$ & & & & $\begin{array}{l}0.0000 \\
(0.00001)\end{array}$ \\
\hline$S c$ & $\begin{array}{r}0.0575 \\
(0.0478) \\
\end{array}$ & $\begin{array}{r}0.0620 \\
(0.0480) \\
\end{array}$ & $\begin{array}{r}0.0590 \\
(0.0478) \\
\end{array}$ & $\begin{array}{l}0.0637 \\
(0.0477)\end{array}$ \\
\hline Constant & $\begin{array}{c}-0.2415^{* *} \\
(0.1163) \\
\end{array}$ & $\begin{array}{l}-0.2082 * \\
(0.1163)\end{array}$ & $\begin{array}{c}-0.2465 * * \\
(0.1172)\end{array}$ & $\begin{array}{l}-0.2054 * \\
(0.1171)\end{array}$ \\
\hline Year dummies & Yes & Yes & Yes & Yes \\
\hline $\begin{array}{l}\text { Number of samples } \\
\text { Number of groups } \\
\text { Log likelihood } \\
\text { Hausman specification } \\
\text { test }\end{array}$ & $\begin{array}{c}2324 \\
311 \\
-6992.978 \\
\text { chi2 }(18)=89.77 \\
(\text { prob }>\text { chi } 2=0.00)\end{array}$ & $\begin{array}{c}2324 \\
311 \\
-6988.2725 \\
\text { chi2 }(18)=56.71 \\
(\text { prob }>\text { chi2 }=0.01)\end{array}$ & $\begin{array}{c}2324 \\
311 \\
-6996.9958 \\
\text { chi2 }(16)=98.63 \\
(\text { prob }>\text { chi2 }=0.00)\end{array}$ & $\begin{array}{c}2324 \\
311 \\
-6991.4481 \\
\text { chi2 }(17)=57.99 \\
(\text { prob }>\text { chi2 }=0.00)\end{array}$ \\
\hline
\end{tabular}

Note 1: ***,***: respectively significant at the $10 \%, 5 \%$, and $1 \%$ levels

Note 2: Standard errors in parentheses 
Table (9): Comparison between the impact of market-coordinated collaboration and government-led collaboration. Summary of estimation results (Whole Sample)

\begin{tabular}{|l|c|c|c|c|}
\hline & Model 1 & Model 2 & \multicolumn{1}{c|}{ Model 3 } & Model 4 \\
\hline & $\begin{array}{l}\text { Test if past } \\
\text { participation } \\
\text { affects R\&D } \\
\text { productivity }\end{array}$ & $\begin{array}{l}\text { Test if present } \\
\text { participation } \\
\text { affects R\&D } \\
\text { productivity }\end{array}$ & $\begin{array}{l}\text { Test if past } \\
\text { participation } \\
\text { affects R\&D } \\
\text { productivity } \\
\text { through spillover } \\
\text { effects }\end{array}$ & $\begin{array}{l}\text { Test if present } \\
\text { participation affects } \\
\text { R\&D productivity } \\
\text { through spillover } \\
\text { effects }\end{array}$ \\
\hline $\begin{array}{l}\text { Government } \\
\text { Collaboration }\end{array}$ & Significant (1\%) & Significant (1\%) & Significant (1\%) & Significant (1\%) \\
\hline Elasticity & 0.44 & 0.45 & 7.62 & 0.44 \\
\hline $\begin{array}{l}\text { Market } \\
\text { Collaboration }\end{array}$ & Insignificant & Significant (10\%) & Insignificant & Insignificant \\
\hline Elasticity & & 1.19 & & \\
\hline
\end{tabular}


Appendix 1: List of the 12 government projects related to the robot industry studied in this paper

\begin{tabular}{|c|c|c|c|c|c|}
\hline Name of the program & Period & Participants (firms) & $\begin{array}{l}\text { Budget } \\
\text { (million } \\
\text { yen) }\end{array}$ & $\begin{array}{c}\text { Number of } \\
\text { patents (G1) }\end{array}$ & $\begin{array}{c}\text { Targeted } \\
\text { technologies }\end{array}$ \\
\hline $\begin{array}{l}\text { 1) R\&D on Micromachine } \\
\text { Technology }\end{array}$ & $\begin{array}{l}1991- \\
2000\end{array}$ & $\begin{array}{l}\text { Around } 30 \text { firms (the participants } \\
\text { changed over time), including } \\
\text { Mitsubishi Electric, Yaskawa, } \\
\text { Fanuc, Toshiba, Hitachi }\end{array}$ & 25,000 & $26(34)$ & $\begin{array}{l}\text { Mobile Robots, } \\
\text { Microrobots }\end{array}$ \\
\hline $\begin{array}{l}\text { 2) Mobile Meal Delivery } \\
\text { Robot for Aged and Disabled } \\
\text { People }\end{array}$ & $\begin{array}{l}1994- \\
1998\end{array}$ & 2 (Yaskawa \& Fujitsu) & 563.4 & $4(8)$ & $\begin{array}{l}\text { Mobile Robots, } \\
\text { Safety Devices, } \\
\text { Positioning Control, } \\
\text { Image Processing, } \\
\text { Sound Recognition }\end{array}$ \\
\hline $\begin{array}{l}\text { 3) Surgery Support System } \\
\text { for Brain Tumors }\end{array}$ & $\begin{array}{l}1995- \\
1999\end{array}$ & $\begin{array}{l}3 \text { (Hitachi, Toshiba, NHK } \\
\text { Engineering Services) }\end{array}$ & 931.9 & $4(5)$ & Microrobots \\
\hline 4) Humanoid Robot Project & $\begin{array}{l}1998- \\
2002\end{array}$ & $\begin{array}{l}12 \text { (including ALSOK, Hitachi, } \\
\text { Kawasaki Heavy Industries, } \\
\text { Yaskawa Electric, Kawada } \\
\text { Industries, Honda, Fanuc) in } \\
\text { collaboration with universities and } \\
\text { AIST }\end{array}$ & 4,573 & $23(39)$ & $\begin{array}{l}\text { Master-slave types, } \\
\text { Mobile Robots, } \\
\text { Control of Mobile } \\
\text { Robots, Image } \\
\text { Processing }\end{array}$ \\
\hline $\begin{array}{l}\text { 5) Advanced support system } \\
\text { for endoscopic and other } \\
\text { minimally invasive surgery }\end{array}$ & $\begin{array}{l}2000- \\
2004\end{array}$ & 2 (Toshiba \& Asahi Optical) & $\begin{array}{l}\text { About } \\
850\end{array}$ & $7(8)$ & Master-slave type \\
\hline $\begin{array}{l}\text { 6) Development of a Software } \\
\text { Infrastructure for Robot } \\
\text { Systems (RT Middleware } \\
\text { Project) }\end{array}$ & $\begin{array}{l}2002- \\
2004\end{array}$ & $\begin{array}{l}1 \text { (Matsushita Electric Works) in } \\
\text { collaboration with AIST and } \\
\text { JARA }\end{array}$ & 267 & $1(1)$ & $\begin{array}{l}\text { Control of Mobile } \\
\text { Robots }\end{array}$ \\
\hline
\end{tabular}




\begin{tabular}{|c|c|c|c|c|c|}
\hline $\begin{array}{l}\text { 7) Key Technology Research } \\
\text { and Development for } \\
\text { Humanoid Robots Operating } \\
\text { in Actual Environments }\end{array}$ & $\begin{array}{l}2002- \\
2007\end{array}$ & $\begin{array}{l}2 \text { (Kawada Industries, Kawasaki } \\
\text { Heavy Industries) in collaboration } \\
\text { with AIST }\end{array}$ & No data & $16(21)$ & Mobile robots \\
\hline $\begin{array}{l}\text { 8) Project for the Practical } \\
\text { Application of Next- } \\
\text { Generation Robots }\end{array}$ & $\begin{array}{l}2004- \\
2005\end{array}$ & $\begin{array}{l}\text { Around } 40 \text { (including Matsushita } \\
\text { Electric Works, Mitsubishi Heavy } \\
\text { Industry, ALSOK, Tmsuk, NEC) } \\
\text { in collaboration with many } \\
\text { universities }\end{array}$ & $\begin{array}{l}\text { About } \\
4,000\end{array}$ & $2(3)$ & $\begin{array}{l}\text { Mobile Robots, } \\
\text { Safety Devices }\end{array}$ \\
\hline $\begin{array}{l}\text { 9) R\&D on Medical Welfare } \\
\text { Machinery Technology }\end{array}$ & $\begin{array}{l}1999- \\
2003\end{array}$ & $\begin{array}{l}6 \text { (including Hitachi, Yaskawa } \\
\text { Electric, Daihen Tec, Sanyo } \\
\text { Electric) }\end{array}$ & No data & $6(8)$ & $\begin{array}{l}\text { No Targeted } \\
\text { Technologies }\end{array}$ \\
\hline $\begin{array}{l}\text { 10) Epigenetic Interface for } \\
\text { Appropriating Social } \\
\text { Communication Skills }\end{array}$ & $\begin{array}{l}2002- \\
2004\end{array}$ & $\begin{array}{l}1 \text { (ATR) in collaboration with } \\
\text { universities }\end{array}$ & No data & $4(7)$ & Mobile Robots \\
\hline $\begin{array}{l}\text { 11) R\&D on Human } \\
\text { Information Communication }\end{array}$ & $\begin{array}{l}2002- \\
2006\end{array}$ & $\begin{array}{l}1 \text { (ATR) in collaboration with } \\
\text { universities }\end{array}$ & No data & $7(11)$ & $\begin{array}{l}\text { Mobile Robots, } \\
\text { Artificial } \\
\text { Intelligence, Image } \\
\text { Processing }\end{array}$ \\
\hline $\begin{array}{l}\text { 12) R\&D on Network Human } \\
\text { Interface (Network Robots) }\end{array}$ & $\begin{array}{l}2004- \\
2008\end{array}$ & $\begin{array}{l}5 \text { (ATR, Toshiba, NTT, Mitsubishi } \\
\text { Heavy Industries, Matsushita } \\
\text { Electric Industries) }\end{array}$ & No data & $1(2)$ & $\begin{array}{l}\text { Mobile Robots, } \\
\text { Control of Mobile } \\
\text { Robots }\end{array}$ \\
\hline
\end{tabular}

Source: Compilation of public reports by the authors

Note 1: Programs 1 to 9 are organized by NEDO (METI); programs 10 to 12 are organized by NICT (MIC)

Note 2: In the column "number of patents,", the first figure is the absolute number of G1 patents, while the figure in parenthesis is the number calculated by firms: a collaborative patent is therefore counted as many times as there are different partners. 


\section{Appendix 2: Definition of G2 patents and notion of targeted technology}

In Section 2.2, we distinguish between two types of $\mathrm{G}$ patents, public project related patents, G1 and G2. G1 are patents to which the official reports refer. G2 are government patents defined in a broader sense.

We basically follow Branstetter \& Sakakibara (2002) to identify this second category, but there are two differences. First, in Branstetter and Sakakibara (2002), the public project related patents are defined as the number of patent applications by participating firms in the targeted technologies during the period that the firm participate in consortia. Yet we include the number of patent applications by participating firms in the targeted technologies during and after the period of participation. To put it differently, according to this definition, once a firm participates in a government program, all the patents it applies for in the targeted technologies after the participating year are considered to be G2 patents. Second, to classify the G2 patents, Branstetter \& Sakakibara (2002) use the targeted technologies that are depicted in the official report, yet we use more quantitative criterion, utilizing the information of the technological fields of patents reported by the JPO (2002). We first identified the technological fields of the 94 G1 patents (Table 1). Then, we count the number of patents for each technological field. For each project, the technological fields that have the largest number of patents are defined as the target technologies of the project.

According to this criterion, the targeted technologies for the "Humanoid robot project" are "master slave type," "mobile robots," "control of mobile robots," and "image processing" (respectively $15 \%, 33 \%, 10 \%$, and $13 \%$ of the 39 patents that issued from this project). With this criterion, the number of targeted technologies varies from 5 (for the "Mobile Meal Delivery Robot for Aged and Disabled People") to 0 ("R\&D on Medical Welfare Machinery Technology"). The official target of this program is not RT and the technological fields of the 8 patents that came out of this project are extended to 8 fields; thus, we conclude that there is no target technology in this project. The case for the "Mobile Meal Delivery Robot for Aged and Disabled People" is ambiguous, where the 8 patents are distributed to 7 technological fields. Thus, we use the number of claims of these patents, instead of the number of patents, to determine the targeted technologies.

From this, it can be seen that "mobile robots" appears most frequently as the targeted technological field in the government programs (11 times among 12 programs) while 11 technological fields are not defined as targeted technologies in any of the projects. Generally speaking - and this comes as no surprise - the targeted technologies tend to be the technologies that are closely related to next-generation robots (Figure 2). There is only one exception, "artificial intelligence," which has not been the focus of the commissioned-type of government program. Again, this is not surprising, because this is the domain where universities are actively involved (as seen in Lechevalier, Ikeda, and Nishimura, 2006) and the R\&D in this technology is supported through subsidies from MEXT. 


\section{Appendix 3: Derivation of Spillover Pool}

Firms are usually engaged in research activities in various fields. Jaffe [1986] expresses the technological position of a firm in vectors which are composed of the portion of its R\&D effort in each technological field:

$$
F_{i}=\left(f_{1} \cdot \cdots f_{k}\right)
$$

where each element of the technological position vector represents the ratio of $R \& D$ resources used by firm $i$ in each technological field. One way to calculate the technological position of the firm is by using the distribution of R\&D spending in each field, yet it is quite difficult to obtain the portion of R\&D spending across technological fields. Thus, we follow Jaffe [1986] and use the distribution of patents that a firm applies for in each technological field. To calculate the technological position of firms we classify RT patents into twenty micro-technological fields based on the classification of the JPO (2002).

Further, Jaffe [1986] defines the "technological distance" between firms $i$ and $j$ using their vectors of technological position, which takes the form of:

$$
T_{i j}=\frac{F_{i} F_{j}^{\prime}}{\left[\left(F_{i} F_{i}^{\prime}\right)\left(F_{j} F_{j}^{\prime}\right)\right]^{1 / 2}}
$$

Here, technological distance Tij is an index to measure the magnitude of similarity in the patent portfolio between the firms and it approaches 1 as the similarity of the technological position increases. Following Jaffe [1986], we assume that the technological position and technological proximity are fixed in the short run.

We can then calculate the potential spillover pool of each firm using the index of technological distance. The idea behind this is that spillover effects for firm $i$ will be bigger as its technological position become more similar to that of firm $j$. The spillover pool for the firm $i$ in time $t$ is formularized as:

$$
K_{i t}=\sum_{i \neq j} T_{i j} R_{j t}
$$




\section{Appendix 4: complementary tables}

\section{Table A1 : Estimation of Research Productivity}

Function (Standard errors in parentheses )

\begin{tabular}{|l|c|c|}
\hline \multirow{2}{*}{ Variables } & \multicolumn{2}{|c|}{$\begin{array}{c}\text { Dependent variable: } \\
\text { N (number of claims) }\end{array}$} \\
\cline { 2 - 3 } & Fixed Effects & Random Effects \\
\hline$R$ & $0.0101^{* * *}$ & $0.0105^{* * *}$ \\
& $(0.0003)$ & $(0.00032)$ \\
& $0.0196^{* * *}$ & $0.0250^{* * *}$ \\
Sc & $(0.0066)$ & $0.0061)$ \\
& 0.0535 & 0.0877 \\
Constant & $(0.0482)$ & $0.0451)$ \\
& 0.0713 & 0.0553 \\
Year dummies & $(0.0801)$ & $(0.0797)$ \\
& yes & yes \\
\hline Number of samples & 2324 & 2329 \\
Number of groups & 311 & 316 \\
Log likelihood & -7001.3634 & -8767.8197 \\
\hline Hausman Specification & chi2(16) & Prob>chi2 $=$ \\
test & 152.23 & 0.0000 \\
\hline
\end{tabular}

Note 1: ***, ***: respectively significant at the 10\%, 5\%, and $1 \%$ levels

Note 2: Standard errors in parentheses

Note3: As in Table 4, this table gives the result of the estimation of equation (12) but with an alternative specification regarding the variable $C$. Instead of using the accumulated number of consortia in which a firm $i$ has been involved, we consider the accumulated years of participation in the consortia. 
Table A2 : Estimation of Research Productivity Function using the data of participating firms only - Fixed Effects

\begin{tabular}{|l|c|}
\hline \multicolumn{2}{|c|}{ Dependent variable: $\boldsymbol{N}$ (number of claims) } \\
\hline$R$ & $0.0125^{* * *}$ \\
& $(0.0006)$ \\
& $0.1541^{* * *}$ \\
$S c$ & $(0.0460)$ \\
& 0.0705 \\
Constant & $(0.1216)$ \\
& 0.0842 \\
Year dummies & $(0.1594)$ \\
& yes \\
\hline Number of samples & 393 \\
Number of groups & 36 \\
Log likelihood & -1544.5051 \\
\hline Hausman Specification test & chi2(16) $=122.38$ Prob>chi2 $=$ \\
\end{tabular}

Note 1: ***, ***: respectively significant at the $10 \%, 5 \%$, and $1 \%$ levels Note 2: Standard errors in parentheses 
Table A3 : Estimation of Spillovers Model

\begin{tabular}{|l|c|c|}
\hline \multirow{2}{*}{ Variable Names } & \multicolumn{2}{|c|}{$\begin{array}{c}\text { Dependent variable: } \\
\text { (number of claims) }\end{array}$} \\
\cline { 2 - 3 }$K$ & Fixed Effects & Random Effects \\
\hline$R$ & $0.0101^{* * *}$ & $0.0105^{* * *}$ \\
& $(0.0003)$ & $(0.0003)$ \\
CY & $0.0008^{* * *}$ & $0.0008^{* * *}$ \\
& $(0.0002)$ & $(0.0002)$ \\
Sc & $0.00003^{* *}$ & $0.00004^{* * *}$ \\
& $(0.00001)$ & $(0.00001)$ \\
Constant & 0.0550 & 0.0852 \\
& $(0.00001)$ & $(0.0448)$ \\
Year dummies & $-0.2179^{* *}$ & $-0.2540^{* *}$ \\
& $(0.1162)$ & $(0.1065)$ \\
Number of samples & yes & yes \\
Number of groups & 2324 & 2329 \\
Log likelihood & 311 & 316 \\
\hline Hausman Specification test & chi2(16)=76.05 & Prob $>$ chi2 $=0.0000$ \\
\hline
\end{tabular}

Note 1: ***,***: respectively significant at the $10 \%, 5 \%$, and $1 \%$ levels

Note 2: Standard errors in parentheses

Note 3: As in Table 6, this table reports the results of the estimation of equation (14) but here we use the accumulated years of participation in consortia for the variable $C$, instead of the accumulated number of consortia. 
Table A4 : Estimation of Spillovers Model using the data of participating firms only - Fixed Effects

\begin{tabular}{|l|c|}
\hline \multicolumn{2}{|c|}{ Dependent variable: $\boldsymbol{N}$ (number of claims) } \\
\hline$R$ & $0.0123^{* * *}$ \\
$K$ & $(0.0007)$ \\
& $0.00036^{* * *}$ \\
& $(0.0005)$ \\
Sc & $0.0002^{* * *}$ \\
& $(0.00008)$ \\
Constant & 0.0484 \\
& $(0.1222)$ \\
Year dummies & -0.0568 \\
& $(0.2710)$ \\
\hline Number of samples & yes \\
Number of groups & 393 \\
Log likelihood & 36 \\
\hline Hausman Specification test & -1545.9585 \\
\hline
\end{tabular}

Note $1:{ }^{*},{ }^{* *},{ }^{* *}$ : respectively significant at the $10 \%, 5 \%$, and $1 \%$ levels

Note 2: Standard errors in parentheses

\begin{tabular}{|c|c|c|c|c|}
\hline \multicolumn{5}{|c|}{$\begin{array}{l}\text { Table A5: Comparison between the impact of market-coordinated collaboration and } \\
\text { government-led collaboration. Summary of estimation results (estimations with only the } \\
\text { participants in government programs) }\end{array}$} \\
\hline & Model 1 & Model 2 & Model 3 & Model 4 \\
\hline & $\begin{array}{l}\text { Test if past } \\
\text { participation } \\
\text { affects R\&D } \\
\text { productivity }\end{array}$ & $\begin{array}{l}\text { Test if current } \\
\text { participation affects } \\
\text { R\&D productivity }\end{array}$ & $\begin{array}{l}\text { Test if past } \\
\text { participation } \\
\text { affects R\&D } \\
\text { productivity } \\
\text { through } \\
\text { spillover effects }\end{array}$ & $\begin{array}{l}\text { Test if current } \\
\text { participation affects } \\
\text { R\&D productivity } \\
\text { through spillover } \\
\text { effects }\end{array}$ \\
\hline $\begin{array}{l}\text { Government } \\
\text { Collaboration }\end{array}$ & Insignificant & Significant (1\%) & Insignificant & Significant (1\%) \\
\hline $\begin{array}{l}\text { Market } \\
\text { Collaboration }\end{array}$ & Insignificant & Insignificant & Insignificant & Insignificant \\
\hline
\end{tabular}

